\title{
EFFECT OF BORON FOLIAR APPLICATION AND DIFFERENT COMBINATIONS OF MINERAL AND ORGANIC NITROGEN FERTILIZATION ON GROWTH, CHEMICAL COMPOSITION AND YIELD OF SWEET PEPPER (Capsicum annuum L.). EL-Said, M. E. \\ Vegetable Dept.; Hort. Res. Inst.; Agric. Res. Centre, Cairo, Egypt
}

\begin{abstract}
Two field experiments were performed at El-Baramon, Experimental Station, Dakahlia Governorate, Egypt, during the successive seasons of 2007 and 2008 to study the effect of boron foliar nutrition and different combinations of mineral and organic nitrogen fertilization on growth, chemical composition and yield of sweet pepper cv. California wonder.

The main results could be summarized that:

1- Foliar application of boron at $100 \mathrm{ppm}$ and fertilization with $75 \%$ mineral nitrogen fertilizer $+25 \%$ organic nitrogen resulted significasnt increase of plant height, number of branches, fresh and dry weight.

2-The highest significant values of $\mathrm{A}, \mathrm{B}$, total chlorophyll and carotene as well as $\mathrm{N}, \mathrm{P}, \mathrm{K}$ and $\mathrm{Ca}$ contents in sweet pepper plant leaves were obtained with foliar addition of boron at $100 \mathrm{ppm}$ and fertilization with $75 \%$ mineral nitrogen $+25 \%$ organic nitrogen .

3- Fruit sitting percentage, number of fruits per plant, average fruit weight, fruit yield per plant and total yield per feddan were significantly increased as a result of foliar addition with boron at 100 ppm and fertilization at level of $75 \%$ mineral nitrogen fertilizers $+25 \%$ organic nitrogen.

4- Foliar nutrition of boron at $100 \mathrm{ppm}$ and fertilization by $75 \%$ mineral nitrogen $+25 \%$ organic nitrogen significantly increased fruit length, fruit diameter, fruit flesh thickness, fruit dry weigh and TSS as well as vit C.

In general, this study demonstrated that it is possible to produce highest growth, yield and quality of sweet pepper fruits by foliar application with boron at $100 \mathrm{ppm}$ and fertilization using $75 \%$ from the recommended dose as mineral nitrogen plus $25 \%$ from the recommended dose as organic nitrogen.
\end{abstract}

\section{INTRODUCTION}

Sweet pepper (Capsicum annuum L.) is one of the most important vegetable crops grown in Egypt for local utilization and export. Boron is one of the essential micronutrients required for plant growth and productivity. It plays a very important role in cell wall synthesis, RNA metabolism, and root elongation as well as phenols metabolism, also boron involved in pollen and tube growth as mentioned by Srivastava and Gupta, 1996). Moreover, favorable boron nutrition is important for good plant growth and yield (Ashour and El-Fouly, 1970) on tomato; (Abd El-Maksoud et al., 1974) on sweet pepper, (Amer; 1981, Agwah and Mahmoud, 1994) on tomato; (Sharma, 1999) on pepper. Nitrogen plays a major role in plant growth and development, its shortage within plant tissue resulted in reduction in foliage 
and roots expansion, loss in photosynthetic efficiency and disturbance of all metabolitic functions (Marschner, 1995). Excess addition of mineral nitrogen fertilizers causes a major series problem for environment and contamination the underground water as well as led to an accumulation the edible parts (AlGosaibi, 1994;Badiane et al., 1994). Many investigators noticed that mineral nitrogen had an important role for enhancing growth characters of sweet pepper plants (Qawasmi et al., 1999; Palada et al., 1999 and Byoung Ryong., 1999), chlorophyll content, N, P and K contents in plant foliage (Simonne et al., 1998), flowering, fruit characters and quality (Maya et al., 1997), number of fruits (Palada et al., 1999) and total yield (Palada et al., 1999). Furthermore, NPK fertilizers play a significant role in successful tomato production (Jack et al., 2006). Increasing interest in utilization of organic vegetables increased the using of various organic wastes in agriculture. Chicken or poultry manures are a by-product of chicken farms in Egypt, the superior effect of applied amendments of chicken manure compared with NPK on enhancing plant growth parameters and yield are mainly due to the relatively high contents of organic matter, essential macro and micro nutrients of chicken manure (El-Sayed et al., 2002). Poultry manure contains high contents of all the mineral nutrients needed by the plants, moreover, application of poultry manure increased plant height, leaf area and number of branches of pepper (Alabi, 1995). ElBanna and Abd El-Salam ,2000) reported that organic manure such as chicken manure or poultry manure enhanced potato plant vegetative growth through their effect on physical, chemical and biological properties of soils. Alabi, (2006) showed that poultry manure is a cheap organic source to obtain and enhances pepper fruit length and diameter, number of fruits per plant, yield per plant and yield/ha. Moreover, Abd-Alla et al., (2001) found that fertilization of eggplant with chicken manure at rate 15 ton / feddan in combination with $80 \mathrm{~kg} \mathrm{~N} / f e d d a n$ resulted in the highest fruit weight and total yield.

This study was carried out to evaluate the response of sweet pepper to boron foliar nutrition and different combinations between mineral and organic nitrogen fertilization on growth, chemical composition and yield.

\section{MATERIALS AND METHODS}

Two field experiments were conducted at El-Baramon, Experimental Station, Dakahlia Governorate, Egypt, during the two successive seasons of 2007 and 2008. Some physical and chemical properties of the experimental soil at depth of 0-30 $\mathrm{cm}$ are shown in Table1.

Table 1: Physical and chemical properties of the experimental soil during 2007 and 2008 seasons.

\begin{tabular}{|c|c|c|c|c|c|c|c|c|c|}
\hline \multirow{2}{*}{ Seasons } & \multicolumn{2}{|c|}{ Texture\% } & \multirow{2}{*}{\begin{tabular}{|c|}
$\begin{array}{c}\text { Texture } \\
\text { type }\end{array}$ \\
\end{tabular}} & \multirow{2}{*}{$\begin{array}{c}\text { O.M. } \\
\%\end{array}$} & \multirow{2}{*}{$\begin{array}{l}\text { E.C. } \\
\text { dsm }\end{array}$} & \multirow{2}{*}{$\mathrm{pH}$} & \multirow{2}{*}{$\begin{array}{c}\mathbf{N} \\
\text { (ppm) }\end{array}$} & \multirow{2}{*}{$\begin{array}{c}\mathbf{P} \\
(p p m)\end{array}$} & \multirow{2}{*}{$\begin{array}{c}\mathrm{K} \\
\text { (ppm) }\end{array}$} \\
\hline & \begin{tabular}{|l|l|} 
Sand & Silt \\
\end{tabular} & Clay & & & & & & & \\
\hline $1^{\text {st }}$ season & 23.7324 .65 & 50.85 & Clay & 1.32 & 1.07 & 7.6 & 36.50 & 7.10 & 126 \\
\hline $2^{\text {nd }}$ seasons & \begin{tabular}{|l|l|}
22.90 & 23.87 \\
\end{tabular} & 52.40 & Clay & 1.41 & 1.11 & 7.7 & 39.80 & 6.80 & 142 \\
\hline
\end{tabular}


A split plot design with three replicates was used. The main plots were assigned for boron foliar applications levels, meanwhile, the sub plots were divided to mineral and organic nitrogen fertilizers treatments and their combination. Each experimental unit was $12.25 \mathrm{~m}^{2}$ consisted of five ridges each of $3.5 \mathrm{~m}$ long and $70 \mathrm{~cm}$ wide.

The experiment included 15 treatments, which were the combinations between three boron foliar application, i.e., 0,50 and $100 \mathrm{ppm}\left(\mathrm{H}_{3} \mathrm{BO}_{3 ; 16} \%\right.$ $B)$ and five mineral and organic nitrogen fertilization treatments as follows:

1- Organic nitrogen $(\mathrm{N})$ fertilizer ( $100 \% \mathrm{~N}$ from $\mathrm{RD}$ )

2- Mineral nitrogen (25\% form RD+ organic nitrogen ( $75 \%$ form RD) fertilization.

3- Mineral nitrogen (50\% from RD + organic nitrogen (50\%from RD) fertilization.

4- Mineral nitrogen ( $75 \%$ from RD + organic nitrogen (25\% from RD) fertilization.

5- Mineral nitrogen (100\% recommended $\mathrm{N}$ rate) as control.

On $1^{\text {st }}$ March during the two seasons of study, pepper seedlings were transplanted in the open field into one side ridges at spacing $50 \mathrm{~cm}$. Pepper plant were sprayed with boron solutions at 50,65 and 80 days after transplanting. The untreated plants (control) were sprayed with tap water. Chicken manure was incorporated into the soil during soil its preparation, as a source of organic nitrogen and added at 15 ton/ feddan (calculated based on nitrogen percent in the used chicken manure). Chemical properties of organic manure used in the experiment are tabulated in Table 2.

Table (2): Chemical properties of organic manure used in the experiment.

\begin{tabular}{|c|c|c|}
\hline \multirow{2}{*}{ Parameters } & \multicolumn{2}{|c|}{ Chicken manure } \\
\cline { 2 - 3 } & $\mathbf{2 0 0 7}$ & $\mathbf{2 0 0 8}$ \\
\hline Organic manure (\%) & 45.3 & 44.0 \\
\hline Total C (\%) & 28.1 & 26.4 \\
\hline Total N (\%) & 2.0 & 2.11 \\
\hline C / N ratio & 12.2 & 11.1 \\
\hline Total P (\%) & 0.53 & 0.50 \\
\hline Total K (\%) & 1.95 & 1.92 \\
\hline
\end{tabular}

Mineral nitrogen fertilizer was added at $140 \mathrm{Kg} \mathrm{/} \mathrm{fed.} \mathrm{as}$ recommended rate in source of ammonium nitrate $(33.5 \% \mathrm{~N})$ was added as the three equal sub rate after 3,5 and 7 weeks from transplanting date.

Superphosphate $\left(15.5 \% \mathrm{P}_{2} \mathrm{O}_{5}\right)$ was added as only one addition during soil preparation with rate of $60 \mathrm{~kg} \mathrm{P}_{2} \mathrm{O}_{5}$ / feddan.

Potassium sulphate $\left(48 \% \mathrm{~K}_{2} \mathrm{O}\right)$ was added after 5 and 7 weeks from transplanting date with rate at $50 \mathrm{~kg} \mathrm{~K} \mathrm{~K}_{2} \mathrm{O} /$ feddan .

Other normal cultural practices for pepper were followed according to the instruction laid down by Egyptian Ministry of Agriculture. 
Data recorded

Vegetative parameters

A representative sample of 5 plants from each sub plot were taken randomly at 80 days after transplanting to determined plant fresh weight $(\mathrm{g})$, dry weight $(\mathrm{g})$, number of branches and plant height $(\mathrm{cm})$.

\section{Chemical composition}

The chlorophyll A, B and total chlorophyll contents. and Carotene (the forth upper leaves) using spectrophotometer method as described by Mackinny,(1941).

Dry weight of leaves was used to determine nitrogen \% according to the methods described by Bremner and Mulvaney, (1982). Meanwhile, phosphorus was estimated calorimetrically according to Olsen and Sommers (1982) and potassium was also determined by flame photometrically as described by Jackson ,(1967). Calcium was determined by atomic absorption SP method (A.O.A.C, 1990).

\section{Yield and its components}

Five uniform plants of each sub plot were randomly chosen, labeled to determinate fruit setting percentage. All harvested fruits after 50 day from each plot all over the season, were used to determine number of fruits per plant, average fruit weight, yield per plant and total yield per feddan. A representative sample of 10 marketable fruits from each experimental plot were taken at the picking number 4 for determination of fruit length, diameter and shape index (L/D) as well as fruit flesh thickness, fruit dry matter \%, TSS $\%$ and vit C fresh fruit weight according to the methods of A.O.A.C. (1990).

The data were statistically analyzed using the procedure outlined by Snedecor and Cochran, (1980). The treatment means were compared using Duncan's multiple range tests as described by Duncan, (1958).

\section{RESULTS AND DISCUSSION}

\section{Vegetative growth characteristics:}

\subsection{Effect of boron}

Data presented in Table 3 show the effect of boron foliar application on growth characteristics of pepper plants during seasons of 2007 and 2008. Such data indicate clearly that there were differences between the used foliar boron treatments on the studied growth aspects expressed as plant height, plant fresh, dry weight and number of branches, the differences reached the highest level of significant in all the studied growth parameters with the addition 100 ppm compared with control plants during the two seasons.

The results are in agreement with those obtained by Ashour and ElFouly,(1970) they indicated that spraying tomato with $0.01 \%$ of borax improved plant height, leaf area and dry weight per plant. Sharma ,(1999) obtained that fertilization of pepper plants with boron increased vegetative growth characters.

Abd El-Maksoud et al., (1974) on sweet pepper found that foliar nutrition of boron increased plant height and number of branches. Similar 
results are confirmed by Amer, (1981) and Agwah and Mahmoud, (1994) on tomato they showed that three foliar sprayers with borax $(10.6 \% \mathrm{~B})$ at $0.25 \%$ increased tomato leaf dry matter.

Table 3: Effect of foliar application with boron on growth characteristics of sweet pepper plants during 2007 and 2008 seasons.

\begin{tabular}{|c|c|c|c|c|c|c|c|c|}
\hline $\begin{array}{c}\text { Boron } \\
\text { (ppm) }\end{array}$ & \multicolumn{2}{|c|}{ Plant height (cm) } & \multicolumn{2}{|c|}{ No. branches/ plant } & \multicolumn{2}{|c|}{ Fresh weight/plant (g) } & \multicolumn{2}{|c|}{ wry weight/plant (g) } \\
\hline $\begin{array}{c}\text { 0 } \\
\text { (control) }\end{array}$ & $54.05 \mathrm{c}$ & $57.08 \mathrm{c}$ & $9.80 \mathrm{c}$ & $10.77 \mathrm{c}$ & $827.5 \mathrm{~b}$ & $839.3 \mathrm{~b}$ & $139.0 \mathrm{~b}$ & $142.9 \mathrm{~b}$ \\
\hline 50 & $56.88 \mathrm{~b}$ & $59.95 \mathrm{~b}$ & $10.10 \mathrm{~b}$ & $11.19 \mathrm{~b}$ & $842.8 \mathrm{ab}$ & $861.6 \mathrm{a}$ & $141.2 \mathrm{ab}$ & $143.1 \mathrm{~b}$ \\
\hline 100 & $60.03 \mathrm{a}$ & $62.64 \mathrm{a}$ & $10.66 \mathrm{a}$ & $11.64 \mathrm{a}$ & $853.8 \mathrm{a}$ & $893.6 \mathrm{a}$ & $145.7 \mathrm{a}$ & $151.2 \mathrm{a}$ \\
\hline
\end{tabular}

Means followed by the same letter(s) within each column do not significantly differ using Duncan's Multiple Range Test.

\subsection{Effect of mineral and organic $\mathrm{N}$-fertilizers.}

Data in Table 4 show the effect of mineral and organic nitrogen fertilizers treatments on growth characters of pepper plants, it is evident clear that plant height, number of branches, fresh and dry weight were reached the highest significant increase due to fertilization of pepper plants with $75 \%$ mineral nitrogen $+25 \%$ organic nitrogen compared with $100 \%$ of mineral nitrogen (control). These results were true during both seasons.

Table 4: Effect of mineral and organic nitrogen fertilization on vegetative growth characteristics of sweet pepper during 2007 and 2008 seasons

\begin{tabular}{|c|c|c|c|c|c|c|c|c|}
\hline $\begin{array}{c}\text { Fertilizer } \\
\text { combinations } \\
\text { (\% of RD }\end{array}$ & \multicolumn{2}{|c|}{ Plant height (cm) } & \multicolumn{2}{c|}{$\begin{array}{c}\text { No. branches/ } \\
\text { plant }\end{array}$} & \multicolumn{2}{c|}{$\begin{array}{c}\text { Fresh } \\
\text { weight/plant(g) }\end{array}$} & $\begin{array}{c}\text { Dry weight/plant } \\
\text { (g) }\end{array}$ \\
\cline { 2 - 9 } & $\mathbf{2 0 0 7}$ & $\mathbf{2 0 0 8}$ & $\mathbf{2 0 0 7}$ & $\mathbf{2 0 0 8}$ & $\mathbf{2 0 0 7}$ & $\mathbf{2 0 0 8}$ & $\mathbf{2 0 0 7}$ & $\mathbf{2 0 0 8}$ \\
\hline${ }^{\star *} \mathrm{ON}(100 \%)$ & $51.99 \mathrm{~d}$ & $55.01 \mathrm{~d}$ & $8.42 \mathrm{~d}$ & $10.03 \mathrm{c}$ & $772.4 \mathrm{~d}$ & $796.0 \mathrm{e}$ & $132.6 \mathrm{c}$ & $133.0 \mathrm{~d}$ \\
\hline $\mathrm{MN}(25 \%)+\mathrm{ON}(75 \%)$ & $53.22 \mathrm{~d}$ & $57.34 \mathrm{c}$ & $9.67 \mathrm{c}$ & $11.18 \mathrm{~b}$ & $809.8 \mathrm{c}$ & $820.1 \mathrm{~d}$ & $135.9 \mathrm{c}$ & $143.3 \mathrm{c}$ \\
\hline $\mathrm{MN}(50 \%)+\mathrm{ON}(50 \%)$ & $57.69 \mathrm{c}$ & $61.54 \mathrm{~b}$ & $10.33 \mathrm{bc}$ & $11.48 \mathrm{~b}$ & $854.5 \mathrm{~b}$ & $875.8 \mathrm{c}$ & $145.8 \mathrm{~b}$ & $147.2 \mathrm{~b}$ \\
\hline $\mathrm{MN}(75 \%)+\mathrm{ON}(25 \%)$ & $62.11 \mathrm{a}$ & $64.55 \mathrm{a}$ & $11.72 \mathrm{a}$ & $11.90 \mathrm{a}$ & $903.1 \mathrm{a}$ & $927.3 \mathrm{a}$ & $153.1 \mathrm{a}$ & $158.3 \mathrm{a}$ \\
\hline${ }^{* * *} \mathrm{MN}(100 \%$ & $59.92 \mathrm{~b}$ & $61.00 \mathrm{~b}$ & $10.80 \mathrm{~b}$ & $11.41 \mathrm{~b}$ & $867.2 \mathrm{~b}$ & $905.1 \mathrm{~b}$ & $142.4 \mathrm{bc}$ & $151.1 \mathrm{~b}$ \\
\hline
\end{tabular}

Means followed by the same letter(s) within each column do not significantly differ using Duncan's Multiple Range Test.

${ }^{*}$ RD: Recommended dose.

${ }^{\star \star}$ ON: Organic nitrogen.

${ }^{\star \star \star}$ MN: Mneral nitrogen

Similar results were reported by Hsieh and Hsu, (1994) working on sweet pepper showed that plant height significantly increased with fertilizers of chicken manure than with the mineral nitrogen fertilization. ElKassas et al., (1997) reported that chicken manure was the most effective organic source in improving growth and dry weight of sweet pepper. On eggplant, Abd-Alla et al., (2001) studied the effect of mineral $\mathrm{N}$, chicken manure and farmyard manure they found that plant height, fresh and dry weight were increased due to fertilization with chicken manure at the rate $15 \mathrm{ton} /$ feddan in combination with $80 \mathrm{~kg} \mathrm{~N} /$ feddan. Moreover, 
Alabi,(2006) found that poultry manure significantly enhanced plant height, number of leaves, number of branches and leaf area of pepper plants.

The superiority of chicken manure on growth characters may be due to its high $\mathrm{N}$ content which related with the increases of the carbohydrates and protein synthesis and this in turn enhances dry matter accumulation and plant growth (Edmond et al., 1981). Chicken manure, also enhanced plant growth through improving the physical and chemical soil characteristics, i.e., bulk density, hydraulic conductivity, soil strength, water holding, $\mathrm{pH}$ value, organic matter content as well as increasing the available nutrients which in turn extends to plant growth enhancement (El-Sayed et al., 2002, Alabi 2006 and Hati et al., 2006).

\subsection{The effect of interaction between boron and mineral and organic- $\mathrm{N}$ fertilizers.}

Data in Table 5 show the effect of the interaction treatments between boron foliar applications, mineral and organic nitrogen fertilization treatments on growth characters of pepper plants. It is obviously clear that all studied vegetative characters of pepper plants were significantly affected due to the interaction treatments. In this respect, the highest values of pepper plant height, number of branches, fresh and dry weight were recorded with foliar addition of boron at $100 \mathrm{ppm}$ and fertilization with $75 \%$ mineral nitrogen $+25 \%$ organic nitrogen, in both seasons.

Table 5: Effect of interaction between boron foliar application and fertilizer combinations on vegetative growth characteristics of sweet pepper during 2007 and 2008 seasons.

\begin{tabular}{|c|c|c|c|c|c|c|c|c|c|}
\hline \multirow{2}{*}{$\begin{array}{l}\text { Boron } \\
\text { (ppm) }\end{array}$} & \multirow{2}{*}{$\begin{array}{c}\text { Fertilizer } \\
\text { combinations } \\
\left(\% \text { of } R^{\star}\right)\end{array}$} & \multicolumn{2}{|c|}{$\begin{array}{l}\text { Plant height } \\
\text { (cm) }\end{array}$} & \multicolumn{2}{|c|}{$\begin{array}{l}\text { No. branches/ } \\
\text { plant }\end{array}$} & \multicolumn{2}{|c|}{$\begin{array}{c}\text { Fresh } \\
\text { weight/plant (g) }\end{array}$} & \multicolumn{2}{|c|}{$\begin{array}{l}\text { Dry weight } \\
\text { /plant(g) }\end{array}$} \\
\hline & & 2007 & 2008 & 2007 & 2008 & 2007 & 2008 & 2007 & 2008 \\
\hline \multirow{5}{*}{$\begin{array}{c}0 \\
\text { (control) }\end{array}$} & ${ }^{* \star}$ ON $(100 \%)$ & $49.61 \mathrm{~h}$ & $53.08 \mathrm{f}$ & $8.11 \mathrm{~h}$ & $9.23 \mathrm{~g}$ & $.3 \mathrm{e}$ & $769.6 \mathrm{~h}$ & $127.2 \mathrm{~d}$ & $130.0 \mathrm{~d}$ \\
\hline & $\mathrm{MN}(25 \%)+$ & $51.33 \mathrm{gh}$ & $55.67 \mathrm{e}$ & $9.13 \mathrm{~g}$ & $10.54 f$ & de & $787.3 \mathrm{~g}$ & 132. & $139.8 \mathrm{~cd}$ \\
\hline & $\mathrm{MN}(50 \%)+\mathrm{ON}(50 \%)$ & $53.67 \mathrm{fg}$ & $57.67 \mathrm{de}$ & $10.00 \mathrm{f}$ & $11.11 \mathrm{e}$ & $.0 \mathrm{~cd}$ & 859.0cde & 144 & $144.0 \mathrm{bc}$ \\
\hline & $\mathrm{MN}(75 \%)+\mathrm{ON}(25 \%)$ & 57.67cdef & 58.64 cde & $11.42 \mathrm{c}$ & $1.33 \mathrm{cde}$ & $3 \mathrm{~b}$ & $883.2 b c$ & & $151.1 \mathrm{bc}$ \\
\hline & ${ }^{*} \mathrm{MN}(100 \%)$ & $58.00 \mathrm{cde}$ & $60.34 \mathrm{~cd}$ & $10.38 \mathrm{de}$ & $.67 \mathrm{bcd}$ & $3 \mathrm{bc}$ & $\mathrm{Obc}$ & & $149.6 \mathrm{bc}$ \\
\hline \multirow{5}{*}{50} & ${ }^{* \pi} \mathrm{ON}$ & 52.0 & 55.44 ef & $8.21 \mathrm{~h}$ & $10.37 f$ & de & $1 \mathrm{fg}$ & & $132.6 \mathrm{~cd}$ \\
\hline & $\sqrt{(25 \%)}$ & $53.30 \mathrm{fgh}$ & $57.33 \mathrm{de}$ & $9.57 \mathrm{f}$ & $.17 \mathrm{de}$ & & 829.6defg & 134 & $142.0 \mathrm{c}$ \\
\hline & $\sqrt{ }\left(50^{\circ}\right.$ & 57.08def & $62.33 \mathrm{bc}$ & $10.33 \mathrm{e}$ & $3 \mathrm{cde}$ & & $\mathrm{bcd}$ & 146 & $147.5 \mathrm{bc}$ \\
\hline & $\sqrt{(75 \%)}$ & $61.33 b c$ & $64.33 \mathrm{~b}$ & $11.74 \mathrm{~b}$ & $83 \mathrm{bc}$ & $7 \mathrm{bc}$ & $908.9 \mathrm{~b}$ & 150 & $155.5 \mathrm{~b}$ \\
\hline & ${ }^{*} \mathrm{MN}(100 \%)$ & $60.67 \mathrm{bcd}$ & $60.33 \mathrm{~cd}$ & $10.67 \mathrm{de}$ & $11.25 \mathrm{de}$ & $4 \mathrm{~b}$ & $\mathrm{Obc}$ & 142 & $150.6 \mathrm{bc}$ \\
\hline \multirow{5}{*}{100} & ${ }^{* \star} \mathrm{ON}(10$ & 54.34efg & $56.51 \mathrm{de}$ & $8.95 \mathrm{~g}$ & $10.50 f$ & $6 \mathrm{~d}$ & 820.4 efg & $139.0 \mathrm{c}$ & $136.4 \mathrm{~cd}$ \\
\hline & $\mathrm{MN}(25 \%)+\mathrm{ON}(75 \%)$ & $55.04 \mathrm{efg}$ & $59.04 \mathrm{~cd}$ & $10.33 \mathrm{e}$ & $11.83 \mathrm{bc}$ & $837.0 \mathrm{~cd}$ & 843.4cdef & 140. & $148.3 \mathrm{bc}$ \\
\hline & $\mathrm{MN}(50 \%)+\mathrm{ON}(50 \%)$ & $62.33 \mathrm{~b}$ & $64.64 \mathrm{~b}$ & $10.67 \mathrm{~d}$ & $12.00 \mathrm{~b}$ & $872.3 \mathrm{bc}$ & $895.0 \mathrm{bc}$ & $146.2 \mathrm{bc}$ & $150.1 \mathrm{bc}$ \\
\hline & $\mathrm{MN}(75 \%)$ & $67.33 a$ & $70.69 \mathrm{a}$ & $12.00 \mathrm{a}$ & $12.54 a$ & $942.3 \mathrm{a}$ & $990.0 \mathrm{a}$ & $159.1 \mathrm{a}$ & $168.3 \mathrm{a}$ \\
\hline & ${ }^{\star * \star} \mathrm{MN}(100 \%)$ & 61.1 & $32.33 \mathrm{bc}$ & $1.35 c$ & $11.33 \mathrm{cde}$ & $824.0 \mathrm{~cd}$ & $919.3 b$ & $144.2 \mathrm{bc}$ & $153.2 \mathrm{~b}$ \\
\hline
\end{tabular}

Means followed by the same letter(s) within each column do not significantly differ using Duncan's Multiple Range Test.

* RD: Recommended dose. 


\section{Chemical composition of plant foliage:}

\subsection{Effect of boron.}

Concerning the effect of foliar application with boron on chemical composition of pepper plant foliage, data in Table 6 clear that increasing foliar application of boron at dose $100 \mathrm{ppm}$ resulted in the highest significant chlorophyll $A, B$ total chlorophyll $(A+B)$ and carotene as well as $\mathrm{N}, \mathrm{P}, \mathrm{K}$ and $\mathrm{Ca}$ contents in the leaves of pepper plant over the control which showed the lowest values in this respect; the two seasons had the same trend. Similar results were reported by Amer,(1981) and El-Behidei et al.,(1988) working on tomato reported that using boron as foliar application at $100 \mathrm{ppm}$ increased leaves content of $\mathrm{P}$ and K. Moreover, Prabha and Singaram, (1996) found that foliar application of boric acid at $0.3 \%$ resulted in the highest $\mathrm{P}, \mathrm{Mg}, \mathrm{K}$ and $\mathrm{Ca}$ contents.

Table 6: Effect of foliar application of boron on chlorophyll contents and chemical components of sweet pepper leaves during 2007 and 2008 seasons.

\begin{tabular}{|c|c|c|c|c|c|c|c|c|c|c|c|c|c|c|c|}
\hline \multirow{2}{*}{$\begin{array}{l}\text { Boron } \\
\text { (ppm) }\end{array}$} & \multicolumn{2}{|c|}{$\begin{array}{l}\text { Chlorophyll A } \\
\mathrm{mg} / 100 \mathrm{~g}(\mathrm{FW})\end{array}$} & \multicolumn{2}{|c|}{$\begin{array}{l}\text { Chlorophyll B } \\
\text { mg/100gFW }\end{array}$} & \multicolumn{2}{|c|}{\begin{tabular}{c|} 
Total \\
Chlorophyll \\
mg/100g FW
\end{tabular}} & \multicolumn{2}{|c|}{$\begin{array}{c}\text { Carotene } \\
\text { mg/100g } \\
\text { FW }\end{array}$} & \multicolumn{2}{|c|}{ N (\%) } & $\mathbf{P}(\%)$ & \multicolumn{2}{|c|}{ K (\%) } & \multicolumn{2}{|c|}{$\mathrm{Ca}(\%)$} \\
\hline & 2007 & \begin{tabular}{|l|}
2008 \\
\end{tabular} & 2007 & 2008 & 2007 & 2008 & 2007 & 2008 & 2007 & 2008 & 20072008 & 2007 & 2008 & 2007 & 2008 \\
\hline $\begin{array}{c}0 \\
\text { (control) }\end{array}$ & $104.3 \mathrm{~b}$ & $105.0 \mathrm{~b}$ & $49.68 \mathrm{~b}$ & $50.15 \mathrm{~b}$ & $154.0 \mathrm{~b}$ & $4.7 \mathrm{c}$ & 5.3. & $55.24 \mathrm{c}$ & $2.34 \mathrm{c}$ & $2.42 \mathrm{c}$ & $0.175 \mathrm{c}-0.184 \mathrm{c}$ & $2.59 \mathrm{~b}$ & $2.62 \mathrm{c}$ & $2.33 \mathrm{c}$ & 2.3 \\
\hline 50 & $107.64 \mathrm{~b}$ & $112.1 \mathrm{ab}$ & 52 & 51 & $159.7 \mathrm{~b}$ & $164.0 \mathrm{~b}$ & $57.73 \mathrm{~b}$ & $58.83 \mathrm{~b}$ & $2.43 \mathrm{~b}$ & $2.53 \mathrm{~b}$ & \begin{tabular}{|l|l|l|l|l|l|l|}
$0.182 \mathrm{~b}$ & 0.193 \\
\end{tabular} & $2.72 \mathrm{ab}$ & $2.69 \mathrm{~b}$ & $2.43 \mathrm{~b}$ & $2.47 \mathrm{~b}$ \\
\hline 100 & $112.04 \mathrm{a}$ & $113.8 \mathrm{a}$ & 54.32 a & $54.06 \mathrm{a}$ & $166.4 \mathrm{a}$ & $367.9 \mathrm{a}$ & $60.37 \mathrm{a}$ & $60.59 \mathrm{a}$ & $2.52 \mathrm{a}$ & $2.64 \mathrm{a}$ & $0.195 \mathrm{a} \mid 0.202 \mathrm{a}$ & $2.77 \mathrm{a}$ & $2.81 \mathrm{a}$ & $2.54 \mathrm{a}$ & 2.58 \\
\hline
\end{tabular}

\subsection{Effect of mineral and organic $\mathrm{N}$-fertilizers.}

Data presented in Table 7 show the effect of mineral and organic nitrogen combination treatments on the chemical composition of sweet pepper plants foliage expressed as chlorophyll A,B, total chlorophyll and carotene as well as percentage of $N, P, K$ and $C a$ contents. It is clear that all used fertilization treatments affected a significantly on chlorophyll $A$, $\mathrm{B}$, total chlorophyll $(\mathrm{A}+\mathrm{B})$ and carotene as well as $\mathrm{N}, \mathrm{P}, \mathrm{K}$ and $\mathrm{Ca}$ contents in sweet pepper plant leaves. The same data showed also that applying $75 \%$ mineral nitrogen $+25 \%$ organic nitrogen resulted in the highest significant values in this respect compared with the control treatment (100\% mineral nitrogen) and other treatments.

The superiority of addition chicken manure with mineral nitrogen may be due to the fast complete decomposition of organic matter in chicken manure and release nutrients in the available form (Awad et al., 2003). Chicken manures, also enhanced chemical composition plant growth through increasing the available nutrients, i.e., N, P, K, Fe, Mn and $\mathrm{Zn}$, which in turn extends to plant contents of these nutrients and chlorophyll (El-Sayed et al., 2002, Alabi 2006 and Hati et al., 2006). Additionally, the observed increase in mineral composition in leaf tissue with organic manure treatments in general and chicken manure in particular is in agreement with El-Kassas et al. (1997) on sweet pepper. 
EL-Said, M. E. 
J. Agric. Sci. Mansoura Univ., 34 (5), May, 2009 


\subsection{The effect of interaction between boron and mineral as well as organic} $\mathrm{N}$-fertilizers.

Data in Table 8 show the effect of interaction between boron foliar applications, mineral and organic nitrogen fertilization on chemical composition of pepper plants. It is clear that all used combination treatments significantly affected chemical composition of pepper plants. It is clear that the highest values of chlorophyll $A, B$ total chlorophyll $(A+B)$ and carotene as well as percentage of $\mathrm{N}, \mathrm{P}, \mathrm{K}$ and $\mathrm{Ca}$ contents were obtained with foliar addition of boron at dose of $100 \mathrm{ppm}$ and fertilization with $75 \%$ mineral nitrogen $+25 \%$ organic nitrogen.

\section{Yield and its components:}

\subsection{Effect of boron:}

Considering the effect of boron foliar application on fruit yield and yield components of pepper, data presented in Table 9 reveal that increasing boron foliar addition to the highest used rate at (100 ppm) significantly increased fruit sitting percentage, number of fruits per plant, average fruit weight, fruit yield per plant and total yield per feddan comparing with control.

Table 9: Effect of foliar application with boron on yield and yield components of sweet sweet pepper during 2007 and 2008 seasons.

\begin{tabular}{|c|c|c|c|c|c|c|c|c|c|c|}
\hline \multirow{2}{*}{$\begin{array}{c}\text { Boron } \\
\text { (pm) }\end{array}$} & \multicolumn{2}{|c|}{ Fruit sitting \% } & \multicolumn{2}{|c|}{$\begin{array}{c}\text { Average fruit } \\
\text { weight (g) }\end{array}$} & \multicolumn{2}{c|}{ No. fruit / plant } & Yield /plant (g) & \multicolumn{2}{|c|}{$\begin{array}{c}\text { Yield /feddan } \\
\text { (ton) }\end{array}$} \\
\cline { 2 - 10 } & $\mathbf{2 0 0 7}$ & $\mathbf{2 0 0 8}$ & $\mathbf{2 0 0 7}$ & $\mathbf{2 0 0 8}$ & $\mathbf{2 0 0 7}$ & $\mathbf{2 0 0 8}$ & $\mathbf{2 0 0 7}$ & $\mathbf{2 0 0 8}$ & $\mathbf{2 0 0 7}$ & $\mathbf{2 0 0 7}$ \\
\hline $0($ control) & $66.53 \mathrm{c}$ & $69.27 \mathrm{c}$ & $38.54 \mathrm{~b}$ & $40.01 \mathrm{~b}$ & $21.00 \mathrm{c}$ & $22.13 \mathrm{c}$ & $815.48 \mathrm{c}$ & $888.2 \mathrm{C}$ & $10.59 \mathrm{c}$ & $11.54 \mathrm{c}$ \\
\hline 50 & $73.93 \mathrm{~b}$ & $77.00 \mathrm{~b}$ & $41.04 \mathrm{a}$ & $42.10 \mathrm{a}$ & $22.80 \mathrm{~b}$ & $24.27 \mathrm{~b}$ & $940.30 \mathrm{~b}$ & $1019.2 \mathrm{~b}$ & $12.21 \mathrm{~b}$ & $13.24 \mathrm{~b}$ \\
\hline 100 & $77.67 \mathrm{a}$ & $80.47 \mathrm{a}$ & $41.99 \mathrm{a}$ & $43.19 \mathrm{a}$ & $25.00 \mathrm{a}$ & $26.20 \mathrm{a}$ & $1051.1 \mathrm{a}$ & $1132.0 \mathrm{a}$ & $13.66 \mathrm{a}$ & $14.71 \mathrm{a}$ \\
\hline
\end{tabular}

Means followed by the same letter(s) within each column do not significantly differ using Duncan's Multiple Range Test.

Similar results were obtained by Emmert,(1961) who found that applying boron at 100 or $150 \mathrm{ppm}$ increased number of fruits and total yield of tomato. Moreover, Doss et al., (1992) showed that foliar spray with boron at $50 \mathrm{ppm}$ improved pollen grain viability, flowers fertility and fruit setting as well as total yield, number of fruits and average fruit weight per plant of pepper. Meanwhile, Agwah and Mahmoud, (1994) reported that foliar sprayers of $0.25 \%$ borax $(10.6 \% \mathrm{~B})$ increased tomato early and total yields. In similar, Prasad et al., 1997) on tomato and Sharma on pepper, (1999) indicated that fertilization of plants with boron increased total fruit yield.

The simulative effect of boron foliar application on fruit yield of pepper may be due to its enhancing effect on vegetative growth characters (Table 3 ) and chemical components of plant foliage (Table 6) since boron is thought to have a direct effect on synthesis of sugar, protein and soluble nitrogenous compounds (Marchener, 1995), boron, also regulates auxin supply in plants by protecting the indole acetic acid (IAA), it is important for membrane functions which affects the transport of all metabolites required for normal growth and development (Barker and Pilbeam, 2007). 


\subsection{Effect of mineral and organic $\mathbf{N}$-fertilization treatments.}

Data in Table 10 show the effect of mineral and organic nitrogen fertilization treatments on sweet pepper fruit yield and quality, it is clear that, addition of $75 \%$ mineral nitrogen $+25 \%$ organic nitrogen fertilizer significantly enhanced fruit sitting percentage, number of fruits per plant, average fruit weight, fruit yield per plant and total yield per feddan compared with the control treatment $(100 \%$ mineral nitrogen $)$ and other treatments.

Table 10: Effect of mineral and organic nitrogen fertilization application on yield and yield components of sweet pepper fruits during 2007 and 2008 seasons.

\begin{tabular}{|c|c|c|c|c|c|c|c|c|c|c|}
\hline \multirow{2}{*}{$\begin{array}{c}\text { Fertilizer } \\
\text { combinations } \\
\left(\% \text { of } R D^{\star}\right)\end{array}$} & \multicolumn{2}{|c|}{$\begin{array}{c}\text { Fruit sitting } \\
\%\end{array}$} & \multicolumn{2}{|c|}{\begin{tabular}{|c|}
$\begin{array}{c}\text { Average fruit } \\
\text { weight }(\mathrm{g})\end{array}$ \\
\end{tabular}} & \multicolumn{2}{|c|}{$\begin{array}{l}\text { No. fruit / } \\
\text { plant }\end{array}$} & \multicolumn{2}{|c|}{$\begin{array}{c}\text { Yield / plant } \\
(\mathrm{g})\end{array}$} & \multicolumn{2}{|c|}{\begin{tabular}{|c|} 
Yield / \\
feddan (ton) \\
\end{tabular}} \\
\hline & 2007 & 2008 & 2007 & 2008 & 2007 & 2008 & 2007 & 2008 & 2007 & 2008 \\
\hline${ }^{* \star} \mathrm{ON}(100 \%)$ & $65.11 \mathrm{~d}$ & $69.20 \mathrm{~d}$ & $37.75 \mathrm{~d}$ & $39.36 \mathrm{~d}$ & $20.22 \mathrm{~d}$ & $21.89 \mathrm{~d}$ & $771.1 \mathrm{~d}$ & $863.6 \mathrm{e}$ & $10.02 \mathrm{~d}$ & $11.22 \mathrm{e}$ \\
\hline $\mathrm{MN}(25 \%)+\mathrm{ON}(75 \%)$ & $69.56 \mathrm{c}$ & $71.89 \mathrm{c}$ & $39.13 \mathrm{c}$ & $40.61 \mathrm{c}$ & $21.78 \mathrm{c}$ & $23.44 \mathrm{c}$ & $857.5 \mathrm{c}$ & $955.9 \mathrm{~d}$ & $11.14 \mathrm{c}$ & $12.42 \mathrm{~d}$ \\
\hline $\mathrm{MN}(50 \%)+\mathrm{ON}(50 \%)$ & $74.78 \mathrm{~b}$ & $78.78 \mathrm{~b}$ & $41.34 \mathrm{~b}$ & $42.85 \mathrm{~b}$ & $23.78 \mathrm{~b}$ & $25.22 \mathrm{a}$ & $984.7 \mathrm{~b}$ & $1083.2 \mathrm{~b}$ & $12.79 \mathrm{~b}$ & $14.08 \mathrm{~b}$ \\
\hline $\mathrm{MN}(75 \%)+\mathrm{ON}(25 \%)$ & $78.67 \mathrm{a}$ & $81.00 \mathrm{a}$ & $42.82 \mathrm{a}$ & $43.75 \mathrm{a}$ & $25.22 \mathrm{a}$ & $25.89 \mathrm{a}$ & $1080.8 \mathrm{a}$ & $1133.2 \mathrm{a}$ & $14.04 a$ & $14.72 \mathrm{a}$ \\
\hline${ }^{\star * \star} \mathrm{MN}(100 \%)$ & $75.44 \mathrm{ab}$ & $77.00 \mathrm{~b}$ & $41.56 \mathrm{ab}$ & $42.27 \mathrm{~b}$ & $23.67 \mathrm{~b}$ & $24.56 \mathrm{~b}$ & $983.9 \mathrm{~b}$ & $1029.7 \mathrm{c}$ & $12.78 \mathrm{~b}$ & $13.38 \mathrm{c}$ \\
\hline $\begin{array}{l}\text { RD: Recommer } \\
\text { ON: Organic ni } \\
\star \star \star M N: \text { Mineral }\end{array}$ & d do & est. & & & & & & & & \\
\hline
\end{tabular}

These results agree with those reported by Hsieh et al (1994) who mentioned that fruit number and yield of sweet pepper were significantly higher with fertilization by organic nitrogen than with the mineral nitrogen alone. Ouda (2000) demonstrated that chicken manure at rate $15 \mathrm{~m}^{3}$ feddan increased early and total yield of tomato comparing with $100 \%$ mineral nitrogen. Moreover, Youssef et al (2001) showed that addition of $25 \%$ organic manure $+75 \%$ mineral NPK fertilizers gave the best treatment for producing early and total yield, while $75 \%$ organic manure $+25 \%$ mineral fertilizers gave heavier fruit weight of tomato. Additionally, Malak et al (2007) reported that the highest tomato yield was recorded with $25 \%$ chicken manure plus $75 \%$ mineral fertilizers than with $75 \%$ chicken manure plus $25 \%$ mineral fertilizers.

The simulative effect of chicken manure application on fruit yield of pepper may be due to its enhancing effect on vegetative growth characters (Table 4) and chemical components of plant foliage (Table 7), since the decomposition of organic manures due to the microorganisms enhances the release of nutrients slowly to the soil, then nutrients can be adsorbed on the adsorptive sites of organic matter and soil colloids and that protect the nutrients from leaching which in turn extends to fruit yield enhancement (Yassen et al., 2004). 


\subsection{The effect of interaction between boron and mineral as well as organic $\mathbf{N}$-fertilizers.}

Data concerned with the effect of interaction between boron foliar application, mineral and organic nitrogen fertilization on fruit yield and quality of pepper is shown in Table 11. It is clear that foliar addition of boron at $100 \mathrm{ppm}$ and fertilization with $75 \%$ mineral nitrogen $+25 \%$ organic nitrogen significantly increased fruit sitting percentage, number of fruits per plant, average fruit weight, fruit yield per plant and total yield per feddan compared with other treatments during both seasons.

\section{Physical and chemical fruit characters.}

\subsection{Effect of boron.}

Data in Table 12 show the effect of foliar application with boron on quality of pepper fruit characters. It is evident clear that increasing boron foliar additions to the highest used rate at $(100 \mathrm{ppm})$ significantly increased fruit length, fruit diameter, fruit flesh thickness, fruit dry weigh and TSS as well as vit $\mathrm{C}$. The same data showed also that foliar addition of boron at 50 or $100 \mathrm{ppm}$ did not significantly affected pepper fruit shape index in comparing with to control. Those results were in harmony with those obtained by Amer, (1981) who reported that boron foliar application at $100 \mathrm{ppm}$ increased vitamin $\mathrm{C}$ in tomato fruits and in conformity with those obtained by El-Behidei et al., (1988) who found that foliar nutrition with boron has increased TSS of tomato fruits. Moreover, Doss et al., (1992) showed that foliar application of boron at $50 \mathrm{ppm}$ improved vitamin $\mathrm{C}$ on pepper fruits.

Obtained results can be explained in the light of facts that boron is thought to have a direct effect on sugar transport, lignifications, cell wall structure, carbohydrates metabolism and tissue differentiation (Marchener, 1995 and Srivastava and Gupta, 1996) and consequently enhanced fruit quality characters. 
J. Agric. Sci. Mansoura Univ., 34 (5), May, 2009

11

4853 
Table12: Effect of foliar application with boron on some physical and chemical fruit characters of sweet pepper plants during 2007 and 2008 seasons.

\begin{tabular}{|c|c|c|c|c|c|c|c|}
\hline $\begin{array}{c}\text { Boron } \\
(\mathrm{ppm})\end{array}$ & $\begin{array}{c}\text { Fruit } \\
\text { length } \\
(\mathrm{cm})\end{array}$ & $\begin{array}{c}\text { Fruit } \\
\text { diameter } \\
(\mathrm{cm})\end{array}$ & $\begin{array}{c}\text { Shape } \\
\text { index } \\
(\mathrm{L} / \mathrm{D})\end{array}$ & $\begin{array}{c}\text { Fruit flesh } \\
\text { Thickness } \\
(\mathrm{mm})\end{array}$ & $\begin{array}{c}\text { Fruit dry } \\
\text { weight (\%) }\end{array}$ & TSS \% & $\begin{array}{c}\text { Vit C } \\
\mathrm{mg} / 100 \mathrm{~g} \mathrm{FW}\end{array}$ \\
\hline
\end{tabular}

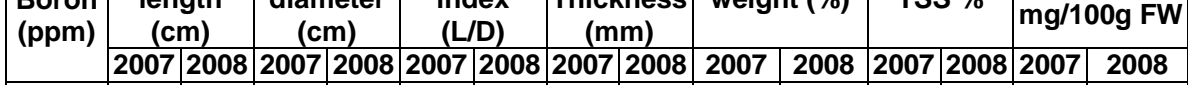

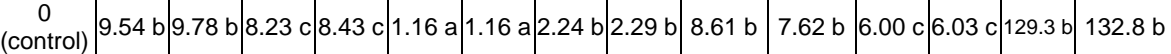
\begin{tabular}{|c|c|c|c|c|c|c|c|c|c|c|c|c|c|c|c|c|}
\hline 50 & $10.37 \mathrm{ab}$ & $10.54 \mathrm{a}$ & $8.73 \mathrm{~b}$ & $8.85 \mathrm{~b}$ & $1.19 \mathrm{a}$ & $1.19 \mathrm{a}$ & $2.36 \mathrm{ab}$ & $2.41 \mathrm{ab}$ & $8.77 \mathrm{ab}$ & $8.10 \mathrm{ab}$ & $6.51 \mathrm{~b}$ & $6.34 \mathrm{~b}$ & $134.1 \mathrm{ab}$ & $138.0 \mathrm{ab}$ \\
\hline
\end{tabular}

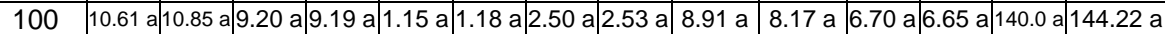
Means followed by the same letter(s) within each column do not significantly differ using Duncan's Multiple Range Test.

\subsection{Effect of mineral and organic $\mathrm{N}$-fertilizers.}

Data presented in Table 13 show the effect of mineral and organic nitrogen combination treatments on some physical and chemical pepper fruit characters. It is evident clear that addition chicken manure at rate of $75 \%$ mineral nitrogen $+25 \%$ organic nitrogen significantly enhanced fruit length, fruit diameter, fruit flesh thickness, fruit dry weigh and TSS as well as vit $\mathrm{C}$. on the other hand, pepper fruit shape index did not significantly affected by all used combination treatments during both seasons of this work.

These results agree with those reported by Hsieh et al., (1994) who reported that pepper fruit size was significantly higher with fertilization by chicken manure than with the mineral nitrogen alone. Youssef et al., (2001) showed that using $25 \%$ organic manure $+75 \%$ mineral NPK fertilizer was the best treatment for producing highest fruit TSS, while $75 \%$ organic manure $+25 \%$ mineral fertilizers gave highest fruit length, fruit diameter and fruit flesh thickness of tomato.

Table 13: Effect of mineral and organic nitrogen fertilization on some physical and chemical fruit characters of sweet pepper plants during 2007 and 2008 seasons.

\begin{tabular}{|c|c|c|c|c|c|c|c|c|c|}
\hline \multirow{2}{*}{$\begin{array}{l}\text { Fertilizer } \\
\text { combinations } \\
\left(\% \text { of } \text { RD }^{\star}\right)\end{array}$} & \multirow{2}{*}{\begin{tabular}{|c|}
$\begin{array}{c}\text { Fruit } \\
\text { length } \\
(\mathrm{cm})\end{array}$ \\
$2007 \mid 2008$
\end{tabular}} & \multirow{2}{*}{\begin{tabular}{|c|}
$\begin{array}{c}\text { Fruit } \\
\text { diameter } \\
\text { (cm) }\end{array}$ \\
$2007 \mid 2008$
\end{tabular}} & \multirow{2}{*}{\begin{tabular}{|c|}
$\begin{array}{c}\text { Shape } \\
\text { index } \\
\text { (L/D) }\end{array}$ \\
20072008
\end{tabular}} & \multicolumn{2}{|c|}{\begin{tabular}{|c|c|} 
Fruit flesh & Fruit dry \\
Thickness & $\begin{array}{c}\text { weight } \\
(\mathrm{mm})\end{array}$ \\
$\begin{array}{c}\text { T\%) } \\
\end{array}$
\end{tabular}} & \multicolumn{2}{|c|}{ TSS \% } & \multicolumn{2}{|c|}{$\begin{array}{l}\text { Vit C mg } \\
/ 100 \mathrm{~g} \mathrm{FW}\end{array}$} \\
\hline & & & & & 20072008 & & 2008 & 2007 & 8 \\
\hline${ }^{\star \star} \mathrm{ON}$ & $9.08 \mathrm{e} 9.36 \mathrm{e}$ & $8.01 \mathrm{e} 8.20 \mathrm{~d}$ & $1.13 \mathrm{a} 1.14 \mathrm{a}$ & \begin{tabular}{|l|l|}
$2.18 \mathrm{e}$ & $2.18 \mathrm{~d}$ \\
\end{tabular} & \begin{tabular}{lll|}
$8.05 \mathrm{e}$ & $7.15 \mathrm{e}$ \\
\end{tabular} & & $2 d$ & & \\
\hline $\mathbb{N}(25$ & \begin{tabular}{|l|l|l|}
$0.50 \mathrm{~d}$ & $9.77 \mathrm{~d}$ \\
\end{tabular} & $8.36 \mathrm{~d} / 8.57 \mathrm{c}$ & \begin{tabular}{|l|l}
$1.14 \mathrm{a}$ & 1. \\
\end{tabular} & \begin{tabular}{|l|l|}
$2.25 \mathrm{~d}$ & $2.26 \mathrm{~d}$ \\
\end{tabular} & \begin{tabular}{l|l}
$8.28 \mathrm{~d} 7$. \\
\end{tabular} & & $7 c$ & & \\
\hline $\overrightarrow{\mathrm{N}(}$ & 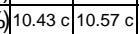 & $8.69 \mathrm{C} / 8.82 \mathrm{~b}$ & $1.20 \mathrm{a} 1$. & \begin{tabular}{|l|l|}
$2.31 \mathrm{c}$ & $2.46 \mathrm{c}$ \\
\end{tabular} & \begin{tabular}{|l|l|}
$8.66 \mathrm{c}$ & $7.98 \mathrm{c}$ \\
\end{tabular} & & $8 \mathrm{~b}$ & $\mathrm{Dc}$ & $3 \mathrm{C}$ \\
\hline $\mathbf{N}(7$ & \begin{tabular}{|c|c|}
$11.11 \mathrm{a}$ & $11.39 \mathrm{a}$ \\
\end{tabular} & \begin{tabular}{|l|l|l|}
$9.43 \mathrm{a}$ & $9.29 \mathrm{a}$ \\
\end{tabular} & $1.18 \mathrm{a} 1.22 \mathrm{a}$ & \begin{tabular}{|l|l|}
$2.58 \mathrm{a}$ & $2.62 \mathrm{a}$ \\
\end{tabular} & \begin{tabular}{|l|l|l}
$9.40 \mathrm{a}$ & $8.64 \mathrm{a}$ \\
\end{tabular} & & $90 \mathrm{a}$ & & \\
\hline${ }^{* * \star}$ MN $(100 \%)$ & \begin{tabular}{|l|l|l|}
$10.76 \mathrm{~b}$ & $10.88 \mathrm{~b}$ \\
\end{tabular} & \begin{tabular}{|l|l|}
$9.12 \mathrm{~b}$ & $9.24 \mathrm{a}$ \\
\end{tabular} & \begin{tabular}{|l|l|}
$1.18 \mathrm{a}$ & 1.17 \\
\end{tabular} & \begin{tabular}{|l|l|}
$2.49 \mathrm{~b}$ & $2.52 \mathrm{~b}$ \\
\end{tabular} & \begin{tabular}{|l|l|l|}
$9.18 \mathrm{~b}$ & 8.25 \\
\end{tabular} & & $6.63 \mathrm{ab}$ & $136.2 \mathrm{~b}$ & \\
\hline \multicolumn{10}{|c|}{$\begin{array}{l}\text { eans followed by the same letter(s) within each column do } \\
\text { uncan's Multiple Range Test. } \\
\text { RD: Recommended dose. } \\
\text { ON: Organic nitrogen. } \\
\text { *MN: Mineral nitrogen }\end{array}$} \\
\hline
\end{tabular}




\subsection{The effect of interaction between boron and mineral as well as organic N-fertilizer.}

Data in Table 14 show the effect of the interaction treatments between boron foliar applications, mineral and organic nitrogen fertilization treatments on some physical and chemical pepper fruit characters. It is clear from such data that foliar addition of boron at $100 \mathrm{ppm}$ and fertilization with $75 \%$ mineral nitrogen $+25 \%$ organic nitrogen significantly increased fruit length, fruit diameter, fruit flesh thickness, fruit dry weigh and TSS as well as vit $\mathrm{C}$.

the same data showed also that fruit shape index did significantly affected by foliar addition of boron at $100 \mathrm{ppm}$ and fertilization with $75 \%$ mineral nitrogen $+25 \%$ organic nitrogen or fertilization with $100 \%$ mineral nitrogen( control).

Finally, from the previous mentioned results and discussion, it could be concluded that it is possible to produce vigor growth, highest fruit and best yield and quality of sweet pepper plants by foliar application of boron at dose of $100 \mathrm{ppm}$ and fertilization with $75 \%$ of the recommended rate of mineral nitrogen fertilizer with $25 \%$ of the recommended rate from organic nitrogen. 
EL-Said, M. E.

T14 


\section{REFERENCES}

A.O.A.C. (1990). Official Method of Analysis. 10 ${ }^{\text {th }}$ Association of Official Analytical Chemists. Inc. USA.

Abd-Alla, E. M. M.; I. M. Darwish and M. R. Mahmoud (2001). Influence of different sources of nitrogen fertilizers on growth and yield of eggplant and some soil characteristics. J. Agric. Sci. Mansoura Univ., 26(3):1655-1673.

Abd El-Maksoud, M.; I. El-Oksh; M. El-Beheidi and M. El-Sawah (1974). Responses of sweet pepper to foliar nutrition with $\mathrm{Zn}, \mathrm{B}$ and sucrose. Zagazig J. Agric. Res., 1(1):17-28.

Agwah, E. M. R. and Mahmoud, H. A. F. (1994). Effect of some nutrients, sucrose and cultivars on tomato fruit set and yield. Bulletin of Faculty of Agriculture, University of Cairo, 45(1):137-148.

Alabi, D. A. (1995). Effect of acetylsalicylic acid on distribution and total photosynthetates in three cultivars of tomato (Lycopersicon esculentus L.) J. Sci. ,29(1):101-109.

Alabi, D. A. (2006). Effects of fertilizers phosphorus and poultry droppings treatments on growth and nutrient components of pepper (Capsicum annuum L.) African Journal of Biotechnology, 5 (8):671-677.

AL-Gosaibi, A. M. (1994). Use of Algae as a soil conditioner for improvement of sandy soils in Al-Ahasa, Saudi Arabia. J. Agric. Sci., Mansoura Univ., 19(5): 1877-1883.

Amer, S. S. A. (1981). Effect of some growth regulators and some minor elements on growth and yield of tomato. M.Sc. Thesis, Fac. Agric. Moshtohor, Zagazig Univ., Egypt.

Ashour, N. I. and M. M. El-Fouly (1970).A preliminary study on the effect of foliar spray with microelements and growth regulators on growth of tomato in winter season. German J. Hort. Sci., 35: 415.

Awad, Y. H.; H. A. Ahmed and O. F. EL-Sedfy (2003). Some chemical properties and NPK availability of sandy soil and yield productivity as affected by some soil organic amendments. Egypt J. Appl. Sci., 18 (2): 356-365.

Badiane, O.; M. Bader, M.R. El-Amir; A. El-Miniawy; F .Goletti and J. Soil (1994). Agricultural input and output market in Egypt: Initial and Future Policy Issues. Paper II. 3 A report Submitted to the MALR, Egypt and Int. Food Policy Res. Inst. Washington, D.C.

Barker, A. V. and D. J. Pilbeam (2007). Handbook of plant nutrition. Taylor and Francis Group. 2 Part Square, Milton Park Abingdon, Oxon OX14 $\mathrm{RN}, \mathrm{UK}$.

Bremner, J. M. and C. S. Mulvaney (1982). Total nitrogen. In: Page, A. L.;R. H. Miller and D. R. Keeney (eds.) Methods of Soil Analysis. Part 2, Amer. Soc. Agron. Madison, W I. USA, 595- 624. 
ByoungRyong, J.; L. EunJoo; B. R. Jeong; E. J. Lee and A. P. Papadopoulos (1999). Growth of plug seedlings of (Capsicum annuum) as affected by ion concentration and $\mathrm{NH} 4: \mathrm{NO} 3$ ratio of nutrient solution. International symposium on growing media and hydroponics, Windsor, Ontario, Canada, Volume I. Acta Horti. (481): 425-431.

Doss, M.: Mervat, E. S. and H. A. El-Sayed (1992). Physiological role of active foliar materials on pepper productivity. J. Agric. Sci. Mansoura Univ. , 17(2):369-375.

Duncan, D.B. (1958). Multiple range and Multiple F test. Biometrics ,11: 142.

Edmond, J. B.; T. L. Senn; F. S. Znderws and R. G. Halfacre (1981). Fundamentals of Horticulture, Published by Tata Mc-Graw-Hill Publishing Co., Limited, Indian.

El-Banna, E. N. and H. Z. Abd El-Salam (2000). Effect of rock phosphate and superphosphate application with organic manures on growth, yield and quality of potato (Solanum tuberosum L.). J. Agric. Sci. Mansoura Univ., 25 (7): 4531-4540.

El-Behidei, M; A. El-Mansy; M. H. Sawah; M. A. El-Gamrini and A. M. Hewedy (1988). Effect of foliar nutrition with $P, K$ and $B$ on flowering, yield and fruit quality of tomato cultivars. Proc. $2^{\text {nd }}$ Hort. Sci. conf. Tanta Univ., Vol (1): 17.

El-Kassas, H. I.; A. F. Abou-Hadid and N. M. H. Eissa (1997). Effect of different organic manures on the yield and elemental composition of sweet pepper plants grown on sandy soil. Egypt. J. Appl. Sci., 12(3):262-281.

El-Sayed, A. K.; S. E. D. B. Ibrahim and A. Awadalla (2002). Utilization of some organic farm residues for improving the productivity of the newly reclaimed soils at El-Fayoum Governorate, Egypt. Egyptian Soil Science Society. $6^{\text {th }}$ Nat. Congress, pp.29-30.

Emmert, E. H. (1961). Effect of boron, dextrose and $\beta$-Noa on fertilizer requirements, yield and fruit quality of tomatoes. Proc. Am. Hort. Sci., 77:494-499.

Hati, K. M.; K. G. Mandai; A. K. Misra; P. K. Ghosh and K. K. Bandyopadhyay (2006). Effect of inorganic fertilizers and farmyard manure on soil physical properties, root distribution, and water use efficiency of soybean in Vertisols of central India. Bioresource Technology, (97):2182-2188.

Hsieh C. F. and K. N. Hsu. (1994). Effect of organic manures on the growth and yield of sweet pepper. Bulletin of Taichung District Agricultural Improvement Station No. 42, 1-10.

Jack, H. E., Syndi, B., Krystle, C. and Axiom, C. (2006). How to grow a tomato plant under different fertility regimes. WikiHow, 1-10.

Jackson, M. L. (1967). Soil Chemical Analysis. Prentic Hall of Indian Private Limited, New Delhi, pp.115.

Mackinny, G. (1941). Absorption of light by chlorophyll solution. J. Bio. Chem., (140): 315-322. 
Malak, A.; E. Ramadan and M. Safia Adam (2007). Effect of chicken manure and mineral fertilizers on distribution of heavy metals in soil and tomato organs Australian Journal of Basic and Applied Sciences, 1(3): 226231.

Marschner, H. (1995). Mineral Nutrition of Higher Plants. Academic Press, London.

Maya P.; S. Natarajan and S. Thamburaj (1997). Flowering, fruit characters and quality as influenced by spacing and $\mathrm{N}$ and $\mathrm{P}$ in sweet pepper cV. California Wonder. South-Indian-Horticulture., 45: 3-4, 125-127.

Olsen, S. R. and L. E. Sommers (1982). Phosphorus. In: Page, A. L., R. H. Miller and D. R. Keeney (eds). Methods of Soil Analysis. Part 2 Amer. Soc. Agron. Madison, W. I. USA, 403-430.

Ouda, A. M. M. (2000). Biological studies on tomato yield and its components. Ph. D. Thesis, Fac. Agric., Mansoura Univ., Egypt.

Palada, M. C.; W. M. Cole and S. M. A. Crossman (1999). Influence of effluents from intensive aquaculture and sludge on growth and yield of bell peppers. J. Sustainable Agric., 14 (4): 85-103.

Prabha, K.; P. Singaram (1996). Effect of boron on the content and uptake of nutrients in tomato. Madras Agric. J., 83(11):745-746.

Prasad K. K.; B. M. Chowdhary; and A. Kumar (1997). Response of tomato to boron application in Chotanagpur region. Journal of Research, Birsa Agricultural University, 9(2):145-147.

Qawasmi, W.; M. J. Mohammad; H. Najim and R. Qubursi (1999). Response of bell pepper grown inside plastic houses to nitrogen fertigation. communications in soil science and Plant Analysis. ,30(17-18): 24992509.

Sharma, S. K. (1999). Effect of boron and calcium on seed production of bell pepper (Capsicum annuum L.) Vegetable Sci., 26 (1): 87-88.

Simonne, E. H.; D. J. Eakes and C. E. Harris (1998). Effects of irrigation and nitrogen rates on foliar mineral composition of bell pepper. J. Plant Nutrition, 21(12): 2545-2555.

Snedecor, G. W. and W. G. Cochran (1968) Statistical methods. lowaStat. Univ. Press, Ame. USA. $6^{\text {th }}$ Ed.p. 593.

Srivastava, P. C. and U. C. Gupta (1996). Trace Elements in Crop Production. Science Pub. Inc. Lebanon, NH03766 USA, 366pp.

Yassen, A. A.; M. A. Khalil and Sahar, M. Zaghloul (2004). Effect of humic substances and farmyard manure in combination with iron on sorghum plants. Egypt. J. Appl. Sci., 19 (6B):784-798.

Youssef, A. M.; A. H. M. El-Fouly; M. S. Youssef and S. A. Mohamadien (2001). Effect of using organic and chemical fertilizers in fertigation system on yield and fruit quality of tomato. Egypt J. Hort., 28 (1): 59-77. 
EL-Said, M. E.

تأثير الرش الورقي بالبورون و توليفات مختلفة من التسميد النيتروجينـي المعدني

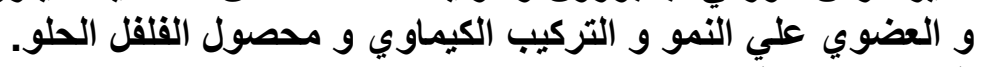

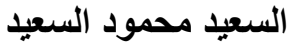

قسم بحوث الخضر - معهل بحوث البساتين - مركز البحوث الزراعية ـ مصر.

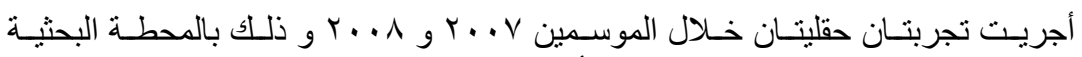

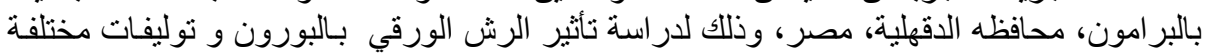

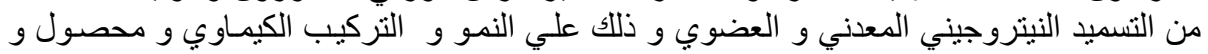

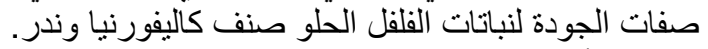

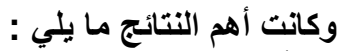

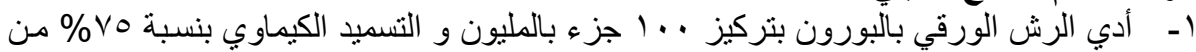

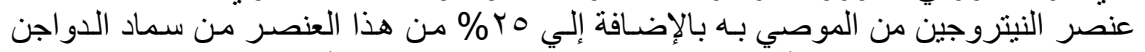

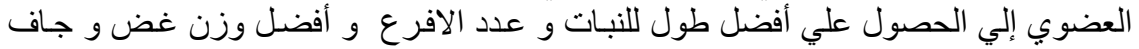

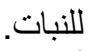

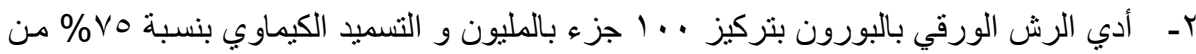

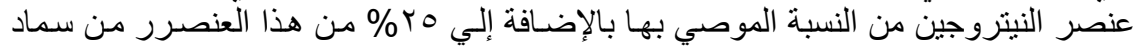

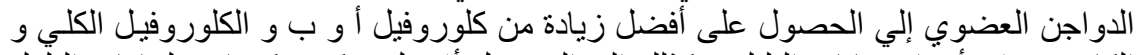

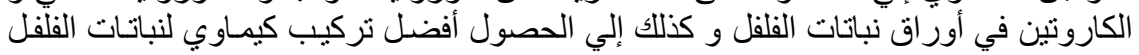

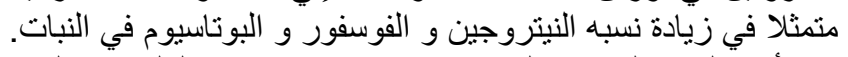

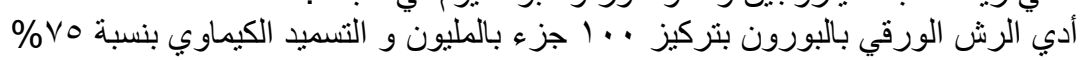

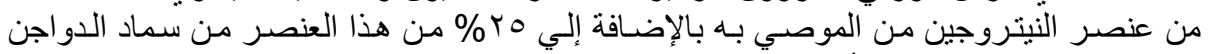

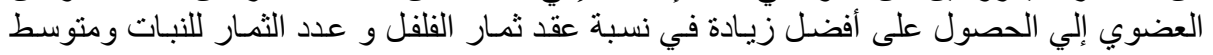

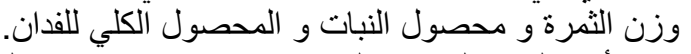

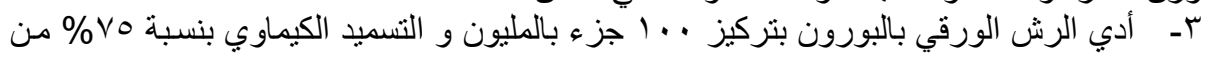

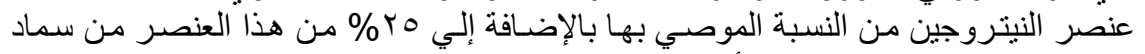

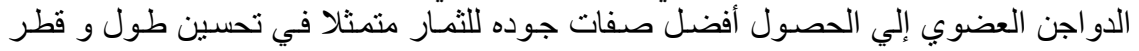
ثمار الفلفل و كذللك سمك اللحم و نسبة المـادة الجافـة و المواد الصلبة الذائبة الكليه و كذلك فيتامين ج.

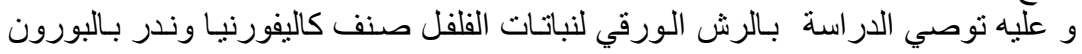

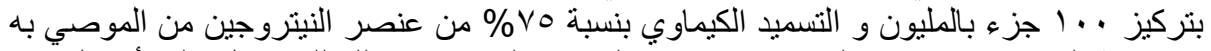

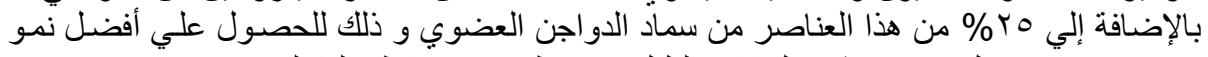
خضري و محصول و جوده ثمار لنباتات الفلفل تحت ظروف لإن محافظه الدقهليه. 


\section{J. Agric. Sci. Mansoura Univ., 34 (5): 4841 - 4860, 2009}

Table 7: Effect of mineral and organic nitrogen fertilization on chlorophyll contents and chemical components of sweet pepper plants during 2007 and 2008 seasons.

\begin{tabular}{|c|c|c|c|c|c|c|c|c|c|c|c|c|c|c|c|c|}
\hline \multirow[t]{2}{*}{$\begin{array}{c}\text { Fertilizer } \\
\text { combinations } \\
\left(\% \text { of } \mathbf{R D}^{\star}\right)\end{array}$} & \multicolumn{2}{|c|}{$\begin{array}{l}\text { Chlorophyll A } \\
\mathrm{mg} / 100 \mathrm{~g} \text { (FW) }\end{array}$} & \multicolumn{2}{|c|}{$\begin{array}{l}\text { Chlorophyll B } \\
\mathrm{mg} / 100 \mathrm{~g} \text { FW }\end{array}$} & \multicolumn{2}{|c|}{$\begin{array}{c}\text { Total } \\
\text { Chlorophyll } \\
\mathrm{mg} / 100 \mathrm{~g} \mathrm{FW}\end{array}$} & \multicolumn{2}{|c|}{$\begin{array}{c}\text { Carotene } \\
\mathrm{mg} / 100 \mathrm{~g} \mathrm{FW}\end{array}$} & \multicolumn{2}{|c|}{$\mathrm{N}(\%)$} & \multicolumn{2}{|c|}{ P (\%) } & \multicolumn{2}{|c|}{$\mathrm{K}(\%)$} & \multicolumn{2}{|c|}{$\mathrm{Ca}(\%)$} \\
\hline & 2007 & 2008 & 2007 & 2008 & 2007 & 2008 & 2007 & 2008 & 2007 & 2008 & 2007 & 2008 & 2007 & 2008 & 2007 & 2008 \\
\hline${ }^{* \star} \mathrm{ON}(100 \%)$ & 105 & $107.2 \mathrm{~b}$ & $48.83 \mathrm{~b}$ & $49.59 \mathrm{~b}$ & $153.9 \mathrm{~b}$ & $156.8 \mathrm{~b}$ & $56.17 \mathrm{~b}$ & b $56.03 \mathrm{~b}$ & $2.22 \mathrm{c}$ & $2.37 \mathrm{C}$ & $0.173 \mathrm{~b}$ & $0.178 \mathrm{c}$ & $2.30 \mathrm{c}$ & $2.38 \mathrm{c}$ & $2.18 d$ & $2.31 \mathrm{~b}$ \\
\hline $\begin{array}{c}\mathrm{MN}(25 \%)+\mathrm{ON} \\
(75 \%)\end{array}$ & $107.4 \mathrm{a}$ & $107.3 \mathrm{~b}$ & $51.65 \mathrm{~b}$ & $51.19 b$ & $159.0 \mathrm{~b}$ & $159.1 \mathrm{~b}$ & $55.72 \mathrm{~b}$ & b $57.78 \mathrm{~b}$ & $2.30 \mathrm{bc}$ & $2.43 \mathrm{c}$ & $0.180 \mathrm{~b}$ & $0.188 b$ & $2.35 \mathrm{bc}$ & $2.44 \mathrm{bc}$ & $2.38 \mathrm{c}$ & $2.40 \mathrm{~b}$ \\
\hline $\begin{array}{c}\mathrm{MN}(50 \%)+\mathrm{ON} \\
(50 \%)\end{array}$ & $108.6 \mathrm{a}$ & $111.4 \mathrm{ab}$ & $53.82 \mathrm{ab}$ & $52.37 \mathrm{~b}$ & $162.4 \mathrm{ab}$ & $163.8 \mathrm{ab}$ & $57.51 \mathrm{~b}$ & $b \mid 58.62 b$ & $2.46 \mathrm{~b}$ & $2.58 \mathrm{~b}$ & $0.186 b$ & $0.192 b$ & $2.46 \mathrm{~b}$ & $2.58 \mathrm{~b}$ & $2.54 \mathrm{~b}$ & $2.60 \mathrm{ab}$ \\
\hline $\begin{array}{c}\text { MN }(75 \%)+\text { ON } \\
(25 \%)\end{array}$ & $111.3 \mathrm{a}$ & $116.5 \mathrm{a}$ & $55.74 \mathrm{a}$ & $55.36 \mathrm{a}$ & $167.0 \mathrm{a}$ & 171 & $61.69 \mathrm{a}$ & $88 \mathrm{a}$ & $2.67 \mathrm{a}$ & $2.73 \mathrm{a}$ & 0. & $3 \mathrm{a}$ & $2.60 a$ & $2.70 \mathrm{a}$ & $2.65 \mathrm{a}$ & $2.64 \mathrm{a}$ \\
\hline${ }^{* * *} \mathrm{MN}(100 \%)$ & $107.1 \mathrm{a}$ & $108.1 \mathrm{~b}$ & $50.65 \mathrm{~b}$ & $51.86 \mathrm{~b}$ & $157.7 b$ & $160.0 \mathrm{~b}$ & $57.97 b$ & $57.75 \mathrm{~b}$ & $2.44 \mathrm{~b}$ & $2.54 \mathrm{~b}$ & 0.180 & $0.196 \mathrm{~b}$ & $2.44 b$ & $2.54 \mathrm{~b}$ & $2.41 \mathrm{c}$ & $2.39 \mathrm{a}$ \\
\hline
\end{tabular}

Means followed by the same letter(s) within each column do not significantly differ using Duncan's Multiple Range Test.

${ }^{*} \mathrm{RD}$ : Recommended dose.

${ }^{* *} \mathrm{ON}$ : Organic nitrogen.

${ }^{\star * *}$ MN: Mineral nitrogen 


\section{EL-Said, M. E.}

Table 8: Effect of interaction between boron foliar application and fertilizer combinations on chlorophyll contents and chemical components of sweet pepper plants during 2007 and 2008 seasons.

\begin{tabular}{|c|c|c|c|c|c|c|c|c|c|c|c|c|c|c|c|c|c|}
\hline \multirow[t]{2}{*}{$\begin{array}{l}\text { Boron } \\
(\mathrm{ppm})\end{array}$} & \multirow{2}{*}{$\begin{array}{c}\text { Fertilizer } \\
\text { Combinat- } \\
\text { ions } \\
\left(\% \text { of } \mathrm{RD}^{\star}\right)\end{array}$} & \multicolumn{2}{|c|}{$\begin{array}{l}\text { Chlorophyll A } \\
\mathrm{mg} / 100 \mathrm{~g}(\mathrm{FW})\end{array}$} & \multicolumn{2}{|c|}{$\begin{array}{l}\text { Chlorophyll A } \\
\mathrm{mg} / 100 \mathrm{~g}(\mathrm{FW})\end{array}$} & \multicolumn{2}{|c|}{$\begin{array}{c}\text { Total } \\
\text { Chlorophyll } \\
\text { mg/100 g FW }\end{array}$} & \multicolumn{2}{|c|}{$\begin{array}{c}\text { Carotene } \\
\mathrm{mg} / 100 \mathrm{~g} \mathrm{FW}\end{array}$} & \multicolumn{2}{|c|}{ N (\%) } & \multicolumn{2}{|c|}{ P (\%) } & \multicolumn{2}{|c|}{ K (\%) } & \multicolumn{2}{|c|}{$\mathrm{Ca}(\%)$} \\
\hline & & 007 & 2007 & 2007 & 2008 & 2007 & 2008 & 2007 & 2008 & 2007 & & 2007 & & 2007 & & 7 & 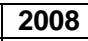 \\
\hline \multirow{5}{*}{$\begin{array}{c}0 \\
\text { (control) }\end{array}$} & ${ }^{* \star} \cap N(100 \%$ & & & & & & de & & & & & & & & & & \\
\hline & & $3.1 \mathrm{~d}$ & 1.3 & $32 \mathrm{~cd}$ & 07 & $2.4 \mathrm{~cd}$ & $150.4 \mathrm{e}$ & 43 & $55.53 \mathrm{~d}$ & $2.27 \mathrm{~g}$ & $8 \mathrm{f}-2=0$ & & $78 \mathrm{c}$ & $\mathrm{fg}$ & $52 \mathrm{~d}$ & $32 \mathrm{~cd}$ & $3 \mathrm{e}$ \\
\hline & & 5.20 & $105.9 \mathrm{de}$ & $51.84 \mathrm{c}$ & $50.21 \mathrm{c}$ & 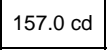 & 1. & $54.67 \mathrm{c}$ & $54.77 \mathrm{~d}$ & 2.3 & $2.49 \mathrm{~d}$ & $0180 \mathrm{bc}$ & $0.184 \mathrm{c}$ & 2.64 ef & $\mathrm{cd}$ & c & $2.45 \mathrm{de}$ \\
\hline & & $6.8 \mathrm{~d}$ & $.0 \mathrm{cde}$ & $4 \mathrm{bc}$ & $84 \mathrm{bc}$ & $.2 \mathrm{~cd}$ & $9 \mathrm{bcd}$ & $58.80 \mathrm{bc}$ & $.73 \mathrm{~cd}$ & $2.52 \mathrm{bc}$ & $2.57 \mathrm{~cd}$ & $184 \mathrm{bc}$ & $191 \mathrm{c}$ & 2.68 ef & $75 \mathrm{c}$ & $2.44 \mathrm{c}$ & $2.49 \mathrm{~d}$ \\
\hline & & & & & & & $\frac{e}{e}$ & & & & & & & & & & \\
\hline \multirow{4}{*}{50} & & $7.4 \mathrm{~cd}$ & & $.24 \mathrm{c}$ & $.98 \mathrm{bc}$ & $159.6 \mathrm{~cd}$ & $163.3 \mathrm{bc}$ & $55.57 \mathrm{c}$ & $58.50 \mathrm{~cd}$ & $2.37 \mathrm{defg}$ & $2.47 \mathrm{~d}$ & .178 bc & $190 \mathrm{bc}$ & 2.69 ef & $2.65 \mathrm{~cd}$ & $2.39 \mathrm{~cd}$ & $.44 \mathrm{de}$ \\
\hline & & $\mathrm{cd}$ & $3.0 \mathrm{bcd}$ & $5 \mathrm{bc}$ & 41 & bc & $5.5 \mathrm{bc}$ & bc & bc & $50 \mathrm{bcd}$ & $59 \mathrm{~cd}$ & $0.185 b c$ & bc & $79 \mathrm{~cd}$ & $c$ & 56 bc & $65 \mathrm{c}$ \\
\hline & & $4 \mathrm{~cd}$ & $7.1 \mathrm{ab}$ & $84 \mathrm{bc}$ & 00 & $3.2 \mathrm{bc}$ & $171.1 \mathrm{~b}$ & 50 & $.50 \mathrm{~b}$ & $2.53 \mathrm{bc}$ & $2.7 .2-3$ & $192 \mathrm{bc}$ & $7 \mathrm{~b}$ & $.84 \mathrm{bc}$ & $2.87 \mathrm{bc}$ & $64 \mathrm{bc}$ & $861 \mathrm{c}$ \\
\hline & & 11 & e & & $50.98 \mathrm{bc}$ & $\begin{array}{ll}\frac{b c}{c d} \\
c d\end{array}$ & \begin{tabular}{|l|l|}
$162.2 \mathrm{bcd}$ \\
$159.6 \mathrm{cdd}$
\end{tabular} & \begin{tabular}{|l|}
5 \\
5 \\
\end{tabular} & $\frac{c}{c d}$ & Bacdaft & $2.51 \mathrm{~d}$ & & & & & & $\frac{32 \mathrm{e}}{38 \mathrm{e}}$ \\
\hline & & $111.7 \mathrm{c}$ & $.3 \mathrm{cde}$ & $41 \mathrm{bc}$ & $.54 \mathrm{bc}$ & bc & bcd & $7 \mathrm{bc}$ & $33 \mathrm{bc}$ & 10 cdefg & & $9 \mathrm{bc}$ & & $2.70 \mathrm{de}$ & & $13 \mathrm{c}$ & 45 \\
\hline & & $113.0 \mathrm{~b}$ & $115.3 \mathrm{bc}$ & $55.98 \mathrm{~b}$ & $54.51 \mathrm{~b}$ & $1689 \mathrm{p}$ & $169.9 \mathrm{~b}$ & $59.43 \mathrm{bc}$ & $6067 \mathrm{bc}$ & $2.57 \mathrm{~b}$ & $2.66 \mathrm{bc}$ & $0.195 b$ & $0.198 \mathrm{bc}$ & $2.89 \mathrm{~b}$ & & b & $2.71 \mathrm{~b}$ \\
\hline & & $0.5 \mathrm{a}$ & & $0.00 \mathrm{a}$ & & & $+\infty$ & | & & a & . & & & $8 a$ & $3.09 \mathrm{a}$ & $87 \mathrm{a}$ & 2.0< a \\
\hline & $0 \%$ & $\begin{array}{c}108.1 \\
\mathrm{~cd}\end{array}$ & $\begin{array}{c}112.6 \\
\text { bcd }\end{array}$ & $21 \mathrm{c}$ & $\begin{array}{c}53.05 \\
\text { bc }\end{array}$ & $\begin{array}{c}160.3 \\
\mathrm{bc}\end{array}$ & $\begin{array}{c}165.7 \\
\mathrm{bc}\end{array}$ & 61 & $\begin{array}{c}60.20 \\
\text { bc }\end{array}$ & $5 b c$ & C & $\begin{array}{c}0.188 \\
b c\end{array}$ & $\begin{array}{c}0.201 \\
\mathrm{bc}\end{array}$ & 2.81 & & & \\
\hline
\end{tabular}

Means followed by the same letter(s) within each column do not significantly differ using Duncan's Multiple Range Test.

* RD: Recommended dose.

${ }^{* *}$ ON: Organic nitrogen.

${ }^{* * * M N}$ : Mineral nitrogen 
Table 11: Effect of interaction between boron foliar application and fertilizer combinations on yield and yield components of sweet pepper fruits during 2007 and 2008 seasons.

\begin{tabular}{|c|c|c|c|c|c|c|c|c|c|c|c|}
\hline \multirow{2}{*}{$\begin{array}{l}\text { Boron } \\
(\mathrm{ppm})\end{array}$} & \multirow{2}{*}{$\begin{array}{c}\text { Fertilizer } \\
\text { combinations } \\
\left(\% \text { of } \mathbf{R D}^{\star}\right)\end{array}$} & \multicolumn{2}{|c|}{ Fruit sitting \% } & \multicolumn{2}{|c|}{$\begin{array}{l}\text { Average fruit weight } \\
\text { (g) }\end{array}$} & \multicolumn{2}{|c|}{ No. fruit / plant } & \multicolumn{2}{|c|}{ Yield /plant (g) } & \multicolumn{2}{|c|}{$\begin{array}{c}\text { Yield / } \\
\text { feddan (ton) }\end{array}$} \\
\hline & & 2007 & 2008 & 2007 & 2008 & 2007 & 2008 & 2007 & 2008 & 2007 & 2008 \\
\hline \multirow{5}{*}{$\begin{array}{c}0 \\
\text { (control) }\end{array}$} & ${ }^{\star \star} \mathrm{ON}(100 \%)$ & $58.67 \mathrm{~h}$ & $62.33 \mathrm{~h}$ & $34.84 \mathrm{~g}$ & $37.90 \mathrm{~h}$ & $17.67 f$ & $19.67 i$ & $615.2 \mathrm{~g}$ & $745.43 j$ & $7.99 \mathrm{~g}$ & $9.69 \mathrm{i}$ \\
\hline & $\mathrm{MN}(25 \%)+\mathrm{ON}(75 \%)$ & $60.67 \mathrm{~h}$ & $63.67 \mathrm{~h}$ & $36.49 f$ & $38.68 \mathrm{~g}$ & $18.33 \mathrm{ef}$ & $20.67 \mathrm{hi}$ & $668.6 \mathrm{~g}$ & $800.2 \mathrm{ij}$ & $8.69 \mathrm{~g}$ & $10.40 \mathrm{i}$ \\
\hline & $\mathrm{MN}(50 \%)+\mathrm{ON}(50 \%)$ & $67.67 \mathrm{fg}$ & 74.00ef & 39.64de & 40.78 efg & $22.00 \mathrm{~cd}$ & 23.33 efg & 872.0ef & $951.59 \mathrm{fg}$ & 11.33 ef & $12.37 f$ \\
\hline & $\mathrm{MN}(75 \%)+\mathrm{ON}(25 \%)$ & $74.33 \mathrm{~cd}$ & $75.33 \mathrm{de}$ & $41.36 \mathrm{bc}$ & $41.69 \mathrm{ef}$ & $24.00 \mathrm{bc}$ & $24.67 \mathrm{de}$ & $992.9 \mathrm{bcd}$ & 1028.3def & $12.90 \mathrm{~cd}$ & $13.36 \mathrm{def}$ \\
\hline & ${ }^{* \star} \mathrm{MN}(100 \%)$ & 71.33de & $71.00 \mathrm{fg}$ & $40.36 \mathrm{~cd}$ & $41.01 \mathrm{f}$ & $23.00 \mathrm{bc}$ & $22.33 f g$ & 928.4de & 915.6gh & $12.06 \mathrm{de}$ & $11.90 \mathrm{~h}$ \\
\hline \multirow{5}{*}{50} & ${ }^{*} \mathrm{ON}(100 \%)$ & $66.33 \mathrm{~g}$ & $70.00 \mathrm{~g}$ & $38.77 \mathrm{e}$ & $39.00 \mathrm{~g}$ & $20.00 \mathrm{de}$ & $22.00 \mathrm{gh}$ & $785.9 f$ & $857.8 \mathrm{hi}$ & $10.21 \mathrm{fg}$ & $11.15 \mathrm{hi}$ \\
\hline & $\mathrm{MN}(25 \%)+\mathrm{ON}(75 \%)$ & $71.33 \mathrm{de}$ & $73.67 \mathrm{gh}$ & $39.60 \mathrm{de}$ & $40.54 f g$ & $22.00 \mathrm{~cd}$ & 23.67defg & 870.7 ef & $959.2 \mathrm{fg}$ & 11.32 ef & $12.47 \mathrm{f}$ \\
\hline & $\mathrm{MN}(50 \%)+\mathrm{ON}(50 \%)$ & $76.67 \mathrm{bc}$ & $79.00 \mathrm{c}$ & $40.90 c$ & $42.91 \mathrm{~cd}$ & $24.33 \mathrm{~b}$ & $25.33 \mathrm{bcd}$ & $995.3 \mathrm{bcd}$ & $1087.0 \mathrm{bcd}$ & $12.93 \mathrm{~cd}$ & $14.13 \mathrm{~cd}$ \\
\hline & $\operatorname{MN}(75 \%)+\mathrm{ON}(25 \%)$ & $79.67 a b$ & $83.00 \mathrm{ab}$ & $43.76 a$ & $45.44 a$ & $24.67 \mathrm{~b}$ & $25.33 \mathrm{cde}$ & $1079.7 \mathrm{~b}$ & $1151.2 \mathrm{ab}$ & $14.03 \mathrm{~b}$ & $14.96 \mathrm{~b}$ \\
\hline & ${ }^{* \star} \mathrm{MN}(100 \%)$ & $75.67 c$ & $79.33 c$ & $42.16 \mathrm{~b}$ & 42.62cde & $23.00 \mathrm{bc}$ & $25.00 \mathrm{cde}$ & $969.7 \mathrm{~cd}$ & $1040.6 \mathrm{cde}$ & $12.60 \mathrm{de}$ & $13.52 \mathrm{~cd}$ \\
\hline \multirow{5}{*}{100} & ${ }^{* *} \mathrm{ON}(100 \%)$ & 70.33ef & 75.33de & $39.66 \mathrm{de}$ & 41.17def & $23.00 \mathrm{bc}$ & $24.00 \mathrm{def}$ & 912.3de & 987.7def & $11.86 \mathrm{de}$ & \begin{tabular}{|l|}
$12.84 \mathrm{ef}$ \\
\end{tabular} \\
\hline & $\mathrm{MN}(25 \%)+\mathrm{ON}(75 \%)$ & $76.67 \mathrm{bc}$ & $78.33 \mathrm{~cd}$ & $41.31 \mathrm{bc}$ & $42.62 \mathrm{de}$ & $25.00 \mathrm{ab}$ & $26.00 \mathrm{abc}$ & $1033.2 \mathrm{bc}$ & $1108.2 \mathrm{bc}$ & $13.43 \mathrm{bc}$ & $14.40 \mathrm{~cd}$ \\
\hline & $\mathrm{MN}(50 \%)+\mathrm{ON}(50 \%)$ & $80.00 a$ & $83.33 \mathrm{ab}$ & $43.48 \mathrm{a}$ & $44.87 a b$ & $25.00 \mathrm{ab}$ & $27.00 \mathrm{ab}$ & $1086.8 \mathrm{ab}$ & $1211.0 \mathrm{a}$ & $14.12 \mathrm{ab}$ & \begin{tabular}{|l|}
$15.74 \mathrm{a}$ \\
\end{tabular} \\
\hline & $\mathrm{MN}(75 \%)+\mathrm{ON}(25 \%)$ & $82.00 a$ & $84.67 a$ & $43.34 a$ & $44.11 \mathrm{ab}$ & $27.00 \mathrm{a}$ & $27.67 a$ & $1169.7 a$ & $1220.3 a$ & $15.20 \mathrm{a}$ & $15.86 \mathrm{a}$ \\
\hline & ${ }^{\star \star \star} \mathrm{MN}(100 \%)$ & 79.33ab & $80.67 \mathrm{bc}$ & $42.15 b$ & $43.19 \mathrm{bc}$ & $25.00 \mathrm{ab}$ & $26.33 a b c$ & $1053.8 \mathrm{bc}$ & $1132.9 \mathrm{~b}$ & $13.69 \mathrm{bc}$ & $14.72 \mathrm{bc}$ \\
\hline
\end{tabular}

Means followed by the same letter(s) within each column do not significantly differ using Duncan's Multiple Range Test.

* RD: Recommended dosage.

${ }^{\star *} \mathrm{ON}$ : Organic nitrogen.

${ }^{* * *}$ MN: Mineral nitrogen 


\section{EL-Said, M. E.}

Table 14: Effect of interaction between boron foliar application and fertilizer combinations on some physical and chemical fruit characters of sweet pepper plants during 2007 and 2008 seasons.

\begin{tabular}{|c|c|c|c|c|c|c|c|c|c|c|c|c|c|c|c|}
\hline \multirow{2}{*}{$\begin{array}{l}\text { Boron } \\
(\mathrm{ppm})\end{array}$} & \multirow{2}{*}{$\begin{array}{c}\text { Fertilizer } \\
\text { combinations } \\
\left(\% \text { of } \mathbf{R D}^{\star}\right)\end{array}$} & \multicolumn{2}{|c|}{$\begin{array}{l}\text { Fruit length } \\
\text { (cm) }\end{array}$} & \multicolumn{2}{|c|}{$\begin{array}{l}\text { Fruit diameter } \\
\text { (cm) }\end{array}$} & \multicolumn{2}{|c|}{$\begin{array}{l}\text { Shape index } \\
\text { (L/D) }\end{array}$} & \multicolumn{2}{|c|}{$\begin{array}{c}\text { Fruit flesh } \\
\text { Thickness (mm) }\end{array}$} & \multicolumn{2}{|c|}{$\begin{array}{c}\text { Fruit dry weight } \\
(\%)\end{array}$} & \multicolumn{2}{|c|}{ TSS \% } & \multicolumn{2}{|c|}{$\begin{array}{l}\text { Vit C mg } \\
/ 100 \mathrm{~g} \mathrm{FW}\end{array}$} \\
\hline & & 2007 & 2008 & 2007 & 2008 & 2007 & 2008 & 2007 & 2008 & 2007 & 2008 & 2007 & 2008 & 2007 & 2008 \\
\hline \multirow{5}{*}{$\begin{array}{c}0 \\
\text { (control) }\end{array}$} & ${ }^{* *} \mathrm{ON}(100 \%)$ & $8.70 \mathrm{i}$ & $9.00 \mathrm{~h}$ & $7.80 \mathrm{i}$ & $8.03 f$ & $1.11 \mathrm{a}$ & $1.12 \mathrm{a}$ & $2.06 \mathrm{e}$ & $2.12 \mathrm{i}$ & $7.90 \mathrm{~h}$ & $6.99 \mathrm{~g}$ & $5.51 \mathrm{i}$ & $5.57 \mathrm{~h}$ & $119.4 \mathrm{~d}$ & $121.0 \mathrm{e}$ \\
\hline & $\mathrm{MN}(25 \%)+\mathrm{ON}(75 \%)$ & $9.00 \mathrm{gh}$ & $9.30 \mathrm{gh}$ & $8.10 \mathrm{gh}$ & $8.40 \mathrm{e}$ & $1.11 \mathrm{a}$ & $1.11 \mathrm{a}$ & $2.13 \mathrm{e}$ & $2.22 \mathrm{~h}$ & $8.18 \mathrm{~g}$ & & & & $125.1 \mathrm{~cd}$ & $127.3 \mathrm{~d}$ \\
\hline & $\overline{M N}(50 \%)+\mathrm{ON}(50 \%)$ & $9.50 \mathrm{gh}$ & $9.70 f$ & $17 \mathrm{gh}$ & $8.40 \mathrm{e}$ & & & $2.23 \mathrm{de}$ & & & & & & & $8 c$ \\
\hline & $\mathrm{MN}(75 \%)+\mathrm{ON}(25 \%)$ & $10.40 \mathrm{~d}$ & $10.60 \mathrm{e}$ & $8.80 \mathrm{~d}$ & $8.70 \mathrm{~cd}$ & $8 a$ & $1.22 \mathrm{a}$ & $2.40 \mathrm{~cd}$ & $2.38 \mathrm{f}$ & $9.09 \mathrm{~d}$ & $8.02 \mathrm{~d}$ & 6. & $8 \mathrm{e}$ & $138.8 \mathrm{bc}$ & $2 \mathrm{bc}$ \\
\hline & ${ }^{\star \star \star} \mathrm{MN}(100 \%)$ & $10.10 \mathrm{fg}$ & $10.30 \mathrm{e}$ & $8.30 \mathrm{fg}$ & 8.60de & & $1.20 \mathrm{a}$ & $2.41 \mathrm{c}$ & $2.41 \mathrm{f}$ & $9.19 \mathrm{~cd}$ & $8.16 \mathrm{~d}$ & $6.44 \mathrm{e}$ & $35 \mathrm{e}$ & $131.9 c$ & $140.1 \mathrm{c}$ \\
\hline \multirow{5}{*}{50} & ${ }^{* *} \mathrm{ON}$ & $9.20 \mathrm{~h}$ & $9.40 \mathrm{~g}$ & $8.07 \mathrm{~h}$ & $8.10 \mathrm{~g}$ & $1.14 \mathrm{a}$ & $1.16 \mathrm{a}$ & $2.16 \mathrm{e}$ & $1 \mathrm{~h}$ & $8.06 \mathrm{gh}$ & $6 \mathrm{~g}$ & 5. & & $127.6 \mathrm{cc}$ & $128.7 \mathrm{~d}$ \\
\hline & $\operatorname{MN}(25 \%)+$ & 9.70gh & $9.87 f$ & 8.40ef & $8.70 \mathrm{~cd}$ & a & $1.13 \mathrm{a}$ & $2.25 \mathrm{de}$ & $9 \mathrm{~g}$ & 8.30 & $3 \mathrm{e}$ & $6.14 \mathrm{f}$ & $3 f$ & $132.7 \mathrm{bc}$ & $2.6 \mathrm{~d}$ \\
\hline & $\mathrm{MN}(50 \%)+\mathrm{ON}(50 \%)$ & $10.67 d$ & $10.80 \mathrm{de}$ & $8.80 \mathrm{~d}$ & $8.97 \mathrm{c}$ & $1.21 \mathrm{a}$ & $1.20 \mathrm{a}$ & $2.32 \mathrm{~d}$ & $2.49 \mathrm{e}$ & $8.93 \mathrm{f}$ & $8.76 \mathrm{~b}$ & $6.44 \mathrm{e}$ & $6.56 \mathrm{~d}$ & $137.5 \mathrm{bc}$ & $138.9 \mathrm{~cd}$ \\
\hline & $\mathrm{MN}(7 !$ & $11.30 \mathrm{~b}$ & $11.53 \mathrm{~b}$ & $9.33 b$ & $9.33 \mathrm{~b}$ & & $1.24 a$ & $2.59 \mathrm{~b}$ & & 9.4 & & & & $136.6 \mathrm{bc}$ & $148.0 \mathrm{~b}$ \\
\hline & ${ }^{* \star \star} \mathrm{MN}$ & $11.00 \mathrm{c}$ & 11. & $07 \mathrm{c}$ & $9.17 \mathrm{bc}$ & Ia & $1.21 \mathrm{a}$ & $2.51 \mathrm{bc}$ & 2. & 9.1 & $6 \mathrm{~d}$ & $7.29 \mathrm{~b}$ & $5 \mathrm{e}$ & $136.4 \mathrm{bc}$ & $142.1 \mathrm{bc}$ \\
\hline \multirow{5}{*}{100} & ${ }^{* *} \mathrm{ON}(100 \%)$ & $9.33 \mathrm{ij}$ & $9.67 f$ & $8.17 \mathrm{gh}$ & $8.47 \mathrm{e}$ & $1.14 \mathrm{a}$ & $1.14 \mathrm{a}$ & $2.32 \mathrm{~d}$ & $2.21 \mathrm{~h}$ & $8.21 \mathrm{fg}$ & $7.32 \mathrm{f}$ & $5.92 \mathrm{~g}$ & $5.82 \mathrm{~g}$ & $131.0 \mathrm{c}$ & $133.0 \mathrm{~d}$ \\
\hline & $\mathrm{MN}(25 \%)+\mathrm{ON}(75 \%)$ & $9.80 \mathrm{~g}$ & 10.13def & $8.57 \mathrm{e}$ & 8.60de & $1.14 \mathrm{a}$ & $1.18 \mathrm{a}$ & $2.37 \mathrm{~cd}$ & $2.28 \mathrm{~g}$ & $8.38 \mathrm{f}$ & $7.39 f$ & $6.22 \mathrm{f}$ & $6.01 \mathrm{fg}$ & $136.2 \mathrm{bc}$ & $138.4 \mathrm{~cd}$ \\
\hline & $\mathrm{MN}(50$ & $11.13 \mathrm{bc}$ & $11.20 \mathrm{cc}$ & $9.10 \mathrm{c}$ & $9.10 \mathrm{bc}$ & $1.22 \mathrm{a}$ & $1.23 \mathrm{a}$ & $2.51 \mathrm{bc}$ & $2.58 \mathrm{~d}$ & $9.10 \mathrm{~d}$ & $8.63 \mathrm{bc}$ & $6.70 \mathrm{~d}$ & $6.80 \mathrm{c}$ & $141.3 \mathrm{~b}$ & $144.6 \mathrm{bc}$ \\
\hline & $\mathrm{MN}(75$ & $11.63 a$ & $12.03 a$ & $10.17 a$ & $9.83 a$ & $1.14 a$ & $1.22 \mathrm{a}$ & $2.76 \mathrm{a}$ & $2.82 \mathrm{a}$ & $9.66 \mathrm{a}$ & & $7.37 \mathrm{a}$ & $7.43 \mathrm{a}$ & & $157.5 \mathrm{a}$ \\
\hline & ${ }^{\star \star \star *} \mathrm{MN}(100 \%)$ & $11.17 \mathrm{bc}$ & $11.23 \mathrm{c}$ & $10.00 \mathrm{a}$ & $9.97 a$ & $1.12 \mathrm{a}$ & $1.13 a$ & $2.57 \mathrm{~b}$ & $2.73 \mathrm{~b}$ & $9.23 \mathrm{c}$ & 8.440 & $7.29 \mathrm{~b}$ & $7.19 \mathrm{~b}$ & $140.5 \mathrm{~b}$ & $147.6 \mathrm{bc}$ \\
\hline
\end{tabular}
Means followed by the same letter(s) within each column do not significantly differ using Duncan's Multiple Range Test. RD: Recommended dose.

${ }^{\star *} \mathrm{ON}$ : Organic nitrogen.

***MN: Mineral nitrogen 